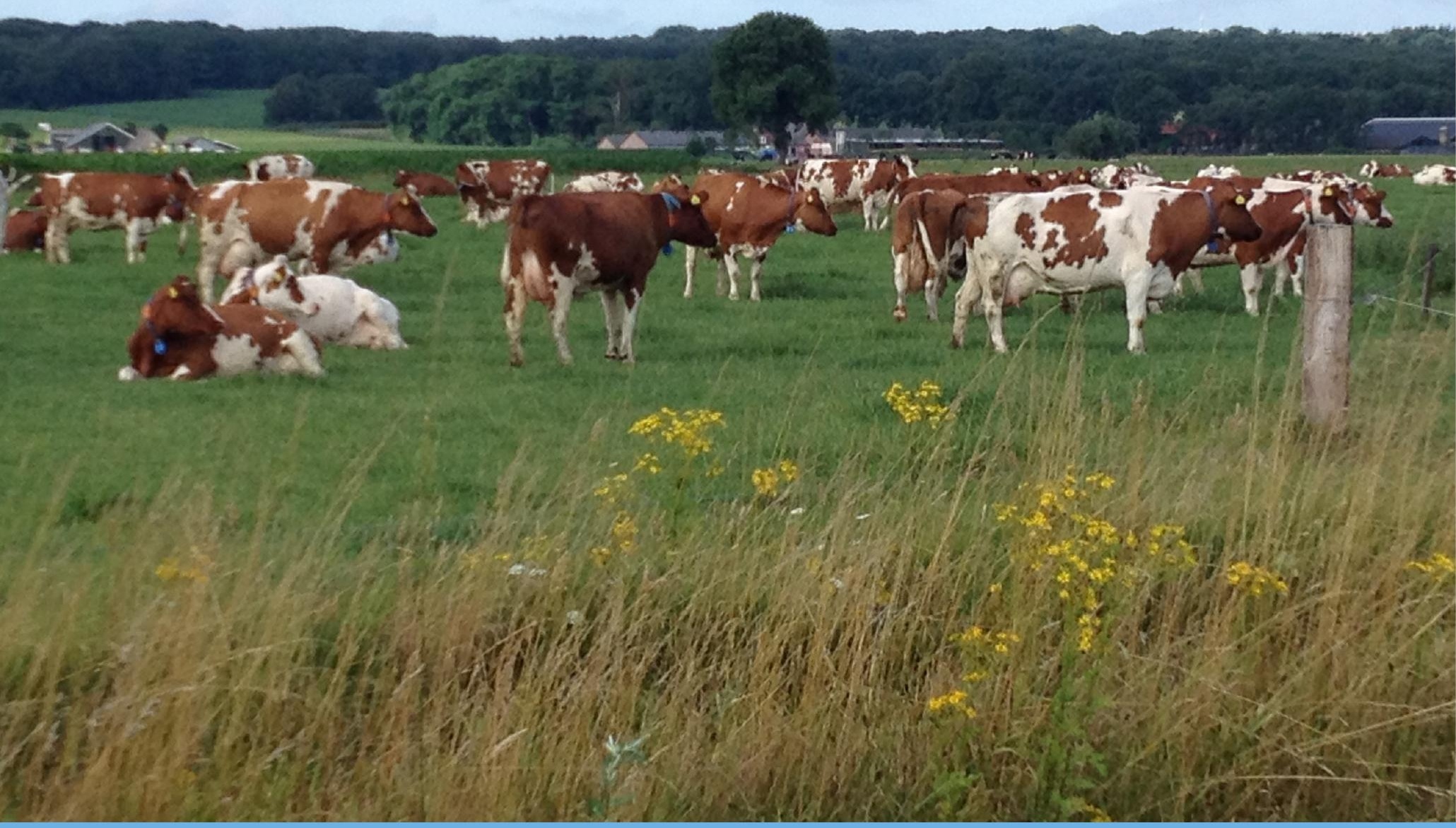

\title{
Vergelijking klimaateffecten van de gangbare vs. de biologische landbouw
}

B.G. Meerburg, R.J.K. Helmes, J.W. Reijs, H.F.M. ten Berge, J.P. Lesschen, T.V. Vellinga 



\title{
Vergelijking klimaateffecten van de gangbare vs. de biologische landbouw
}

B.G. Meerburg' ${ }^{1}$, R.J.K. Helmes ${ }^{2}$, J.W. Reijs², H.F.M. ten Berge ${ }^{3}$, J.P. Lesschen ${ }^{4}$, T.V. Vellinga ${ }^{1}$

\author{
1 Wageningen Livestock Research \\ 2 Wageningen Economic Research \\ 3 Wageningen Plant Research \\ 4 Wageningen Environmental Research
}

Dit onderzoek is uitgevoerd door Wageningen Livestock Research, in opdracht van en gefinancierd door het Ministerie van Landbouw, Natuur en Voedselkwaliteit, in het kader van het Beleidsondersteunend onderzoek (projectnummers BO-43-012.02-026 en BO-43-012.02-032).

Wageningen Livestock Research

Wageningen, juni 2018

Rapport 1109 
Meerburg, B.G., R.J.K. Helmes, J.W. Reijs, H.F.M. ten Berge, J.P. Lesschen en T.V. Vellinga, 2018. Vergelijking klimaateffecten van de gangbare vs. de biologische landbouw. Wageningen Livestock Research, Rapport 1109.

Samenvatting NL

Deze studie vergelijkt de prestaties van gangbare en biologische landbouw- en veehouderijsystemen in Nederland op klimaatgebied. Er is een meta-analyse uitgevoerd naar verschillende bestaande vergelijkende studies en verschillen zijn geduid door onderscheidende factoren te noemen.

\section{Summary UK}

This study compares the environmental performance of conventional and organic agricultural and livestock farming systems in the Netherlands concerning greenhouse gas emissions. A meta-analysis has been carried out into several existing comparative studies and differences have been identified by mentioning differentiating factors.

Dit rapport is gratis te downloaden op https://doi.org/10.18174/451699 of op www.wur.nl/livestock-research (onder Wageningen Livestock Research publicaties).

\section{(c) 2018 Wageningen Livestock Research}

Postbus 338, 6700 AH Wageningen, T 03174839 53, E info.livestockresearch@wur.nl, www.wur.nl/livestock-research. Wageningen Livestock Research is onderdeel van Wageningen University \& Research.

Wageningen Livestock Research aanvaardt geen aansprakelijkheid voor eventuele schade voortvloeiend uit het gebruik van de resultaten van dit onderzoek of de toepassing van de adviezen.

Alle rechten voorbehouden. Niets uit deze uitgave mag worden vermenigvuldigd en/of openbaar gemaakt worden door middel van druk, fotokopie, microfilm of op welke wijze dan ook zonder voorafgaande toestemming van de uitgever of auteur.

Wageningen Livestock Research is NEN-EN-ISO 9001:2015 gecertificeerd. Op al onze onderzoeksopdrachten zijn de Algemene Voorwaarden van de Animal Sciences Group van toepassing. Deze zijn gedeponeerd bij de Arrondissementsrechtbank Zwolle. 


\section{Inhoud}

Woord vooraf $\quad 5$

$\begin{array}{ll}\text { Samenvatting } & 7\end{array}$

$\begin{array}{llr}1 & \text { Inleiding } & 9\end{array}$

$\begin{array}{ll}\text { Methodiek en beperkingen } & 9\end{array}$

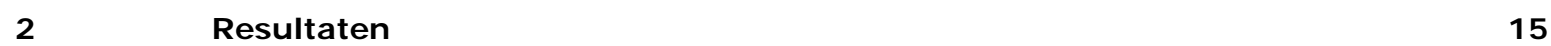

$\begin{array}{lll}2.1 & \text { Primaire productie } & 15\end{array}$

2.2 Post-harvest verschillen tussen gangbaar en biologisch 28

2.2.1 Ketenstappen 28

2.2.2 Afval bij bovenstaande stappen $\quad 29$

$\begin{array}{lll}2.3 & \text { Verhouding Primair vs. Post-Harvest } & 29\end{array}$

$3 \quad$ Discussie en conclusies $\quad 31$

$\begin{array}{ll}\text { Literatuur } & 33\end{array}$

$\begin{array}{lll}\text { Bijlage } 1 & \text { Overzicht bronnen Tabel } 11 & 36\end{array}$ 



\section{Woord vooraf}

Er bestaat veel onduidelijkheid over het verschil tussen gangbare en biologische productie en consumptie wat betreft de emissie van broeikasgassen. Een aantal jaren geleden is in opdracht van het ministerie van LNV een rapport geschreven over energiegebruik en broeikasgassen bij gangbare en biologische landbouw (Bos et al. 2007).

Het ministerie van LNV had behoefte aan een actualisatie van de resultaten en heeft gevraagd om een in een beperkt onderzoek een meta-analyse uit te voeren over alle aspecten in de gehele productieketen en om verschillen in broeikasgasemissies tussen beide systemen te verklaren. Een team onderzoekers van Wageningen UR heeft een quick-scan uitgevoerd op basis van de beschikbare wetenschappelijke literatuur. Er is gekeken naar studies over deelaspecten en naar gehele ketenanalyses (levenscyclus analyse).

Aan de hand van deze meta-analyse is getracht een antwoord te geven over verschillen in de klimaatvriendelijkheid van beide systemen, een verklaring van deze verschillen en de daarbij onderscheidende factoren.

De uitkomsten van deze studie vindt $\mathrm{u}$ in dit rapport.

De auteurs 


\section{Samenvatting}

Dit rapport bevat de uitkomsten van een meta-analyse naar een aantal verschillende productieketens waarin verschillen tussen de biologische en gangbare productiewijzen op het vlak van broeikasgasemissies worden geduid. Uit de meta-analyse blijkt dat een generieke uitspraak waaruit blijkt dat ofwel de gangbare ofwel de biologische productiewijze een betere klimaat impact heeft, op dit moment niet mogelijk is. Dit komt doordat in de productieketens nog vele witte vlekken zijn, die nog onvoldoende in kaart zijn gebracht. Wat wel duidelijk is geworden, is dat bestaande vergelijkende studies die alleen op gewasniveau kijken, te beperkt zijn. Het is belangrijk om de systeemgrenzen goed te duiden en dat er bij het doen van veldproeven ook aandacht wordt besteed aan de nulsituatie. Daarnaast moet worden opgelet dat het streven naar een deelaspect (bijv. het verhogen van het bodemkoolstofgehalte) er niet toe leidt dat uiteindelijk er onbedoelde neveneffecten optreden

(bijvoorbeeld méér emissies van N2O).

Deze studie laat zien dat er op een aantal plekken inderdaad verschillen optreden in broeikasgasemissie tussen de biologische en gangbare productiewijzen. Een belangrijk gegeven is verder dat over het algemeen het leeuwendeel van de klimaat impact ligt bij de primaire productie en dat de impacts verderop in de keten (bijv. transport, opslag, retail en consument) een veel beperktere invloed hebben. 


\section{$1 \quad$ Inleiding}

I eder landbouwsysteem heeft haar eigen karakteristieken. Deze karakteristieken kunnen liggen op verschillende terreinen: bijvoorbeeld op het vlak van economie, productiviteit, milieu, dierenwelzijn en humane gezondheid. De verschillen tussen systemen binnen eenzelfde sector kunnen fors zijn, helemaal als verschillende productiewijzen (biologisch vs. gangbaar worden beschouwd). In een recente studie (Wagenberg et al. 2016) werden de sterke punten van zowel de biologische als de conventionele dierlijke productie (melkvee, vleesvee, varkenshouderij, legpluimveehouderij en vleeskuikenhouderij) op een rij gezet (Tabel 1). Hieruit bleek dat waar op basis van de ene factor de ene productiewijze beter scoort, er aan de andere kant weer voordelen aan de andere productiewijze zitten. Er is dus geen sprake van zwart of wit wat beter is, maar van vele grijstinten.

Tabel 1 Gevonden sterke punten van conventionele en biologische dierlijke productiesystemen (Wagenberg et al. 2016).

\begin{tabular}{|c|c|c|}
\hline & Biologische dierlijke productie & Conventionele dierlijke productie \\
\hline economie & $\begin{array}{l}\text { - Lagere gebouwkosten per dier; } \\
\text { - In de meeste sectoren een hoger inkomen per dier of } \\
\text { per werknemer (fte), grotendeels door de biologische } \\
\text { prijspremie. }\end{array}$ & $\begin{array}{l}\text { - Een lagere arbeidsbehoefte per dier; } \\
\text { - Een lager inkomensrisico per dier. }\end{array}$ \\
\hline productiviteit & & $\begin{array}{l}\text { - Een hogere productie in } \mathrm{kg} \text { product per } \\
\text { dier per tijdseenheid; } \\
\text { - Hogere reproductiecijfers; } \\
\text { - Een lagere voederconversie door } \\
\text { gebalanceerde rantsoenen, hoog } \\
\text { productieve rassen en lager } \\
\text { activiteitsniveaus. }\end{array}$ \\
\hline milieu & $\begin{array}{l}\text { - Een lager eutrofiërings- en verzuringspotentieel per } \\
\text { eenheid land; } \\
\text { - Een lagere impact op lokale biodiversiteit en op } \\
\text { fossiele fosforuitputting per eenheid product. }\end{array}$ & $\begin{array}{l}\text { - Een lager landgebruik en een lager } \\
\text { eutrofiërings- en verzuringspotentieel } \\
\text { per eenheid product, grotendeels door } \\
\text { de hogere gewasopbrengsten en hogere } \\
\text { dierlijke productiviteit. }\end{array}$ \\
\hline dierenwelzijn & $\begin{array}{l}\text { - Een hoger activiteitsniveau en betere } \\
\text { beengezondheid. }\end{array}$ & - Een lager risico op parasitaire infecties. \\
\hline volksgezondheid & $\begin{array}{l}\text { - Een gelijk of lager risico op antibioticaresistentie in } \\
\text { bacteriën in de omgeving van een veehouderijbedrijf, } \\
\text { dieren of dierlijke producten, waarbij dit is toe te } \\
\text { schrijven aan het mindere gebruik van antibiotica om } \\
\text { ziekte in dieren te behandelen of te voorkomen; } \\
\text { - Een hoger niveau van gunstige vetzuren in } \\
\text { koeienmelk, vanwege het hogere aandeel van vers } \\
\text { ruwvoer in het rantsoen. }\end{array}$ & $\begin{array}{l}\text { - Een gelijk of lager niveau van } \\
\text { microbiologische besmetting in dierlijke } \\
\text { producten. }\end{array}$ \\
\hline
\end{tabular}

Waar in de voornoemde studie (Wagenberg et al. 2016) vijf verschillende duurzaamheidsindicatoren werden beschouwd, ligt in deze studie de focus vooral op de twee factoren broeikasgasemissies en productiviteit. Deze twee factoren worden in dit rapport voor een aantal verschillende agrarische sectoren bezien: akkerbouw, tuinbouw, melkveehouderij, varkenshouderij, legpluimveehouderij en vleeskuikenhouderij. Daarbij hebben we ons primair gericht op de vergelijkingen per eenheid product, aangezien dat in termen van klimaat de meest relevante eenheid is.

\section{Methodiek en beperkingen}

Wanneer agrarische systemen worden geanalyseerd op milieu-impact en productiviteit, is het vaak lastig om de bevindingen onderling te vergelijken (Gomiero et al. 2011). Een belangrijke reden die hieraan ten grondslag ligt is dat de grenzen van het systeem op verschillende wijze gedefinieerd kunnen zijn, of dat men het agrarisch systeem versimpelt om zo de analyse te vergemakkelijken. De vraag is bijvoorbeeld als het gaat over energieconsumptie in welke mate de diverse ketenprocessen (bijvoorbeeld transport) in de analyse worden meegenomen. Bovendien hebben agrarische systemen elk hun eigen klimatologische, geografische en bodemkundige karakteristieken en worden er 
verschillende landbouwtechnieken gehanteerd. Aan de andere kant is de beschikbare informatie vanuit Nederland die voldoet aan de door ons gehanteerde randvoorwaarde (peer-reviewed in een journal met een impact factor of een peer-reviewed rapport) zeer beperkt. Daarom werd in deze studie ook buitenlands materiaal betrokken.

Het maakt voor een goede vergelijking ook uit op welke wijze milieuprestaties worden uitgedrukt. Eerdere auteurs (Tuomisto et al. 2012) vergeleken in een studie waarin ze zich afvroegen of biologische productie betere milieuimpacten met zich meebrengt tien indicatoren van beide systemen (Tabel 2) op zowel kwalitatieve als kwantitatieve wijze. De impact werd ofwel gerapporteerd per eenheid product of per eenheid gebruikte grondoppervlak. Hiermee hoopte men de verschillen in kaart te brengen en ook de achterliggende redenen voor de verschillen te verklaren.

Tabel 2

Indicatoren en allocatie eenheden gebruikt door Tuomisto (Tuomisto et al. 2012). Impacts werden gealloceerd ofwel in eenheid grondoppervlak of per eenheid 'product' (bijvoorbeeld per ton graan of varkensvlees).

\begin{tabular}{|l|c|c|}
\hline I ndicator & I mpact per eenheid land & I mpact per eenheid product \\
\hline Soil Organic Matter (SOM) & $\sqrt{ }$ & $\sqrt{ }$ \\
\hline Stikstof lekkage & $\sqrt{ }$ & $\sqrt{ }$ \\
\hline N2O emissies & $\sqrt{ }$ & \\
\hline NH3 emissies & $\sqrt{ }$ \\
\hline P-verliezen & & $\sqrt{ }$ \\
\hline Landgebruik & & $\sqrt{ }$ \\
\hline Energieverbruik & & $\sqrt{ }$ \\
\hline Broeikasgasemissies & & $\sqrt{ }$ \\
\hline Eutrofiering & $\sqrt{ }$ & \\
\hline Verzuring & & \\
\hline Biodiversiteit & & \\
\hline
\end{tabular}

Zoals aangegeven wordt in dit onderzoek expliciet gekeken naar de duurzaamheidsindicatoren productiviteit en klimaat. Het is belangrijk om aan te geven dat bij productiviteit er sprake kan zijn van grote verschillen tussen biologische en conventionele systemen. Vaak wordt in bestaande studies productiviteit gedefinieerd als de hoeveelheid product per dier, bijvoorbeeld het aantal eieren dat door een kip per jaar wordt gelegd. Ook is de complexiteit hoog omdat er soms sprake is van correlatie tussen verschillende factoren (denk bijvoorbeeld aan melkproductie per koe en het vet- en eiwitpercentage in de melk).

Een beperking in de vergelijking is dat er verschillen kunnen optreden in de scores tussen de situatie waar allocatie plaatsvindt naar de hoeveelheid product per dier en de situatie waar allocatie plaatsvindt per eenheid grondoppervlak bij gelijkblijvende productiewijze. Uit de studie van Tuomisto et al. (Tuomisto et al. 2012) is bijvoorbeeld de biologische productiewijze vergeleken met de gangbare en gekeken wat dit doet voor de non-LCA (Life Cycle Assessment) scores (zie Figuur 3). Die auteurs drukten de impact van biologische productie ten opzichte van gangbaar uit in een coëfficiënt die zij (in afwijking van gebruikelijke definitie) 'response ratio' noemden, en definieerden deze als Response ratio $=$ [(impact van biologische productie/impact van gangbare productie) -1$]$. Negatieve waarden van deze coëfficiënt duiden dus op lagere impact bij biologische dan bij gangbare systemen; bij positieve waarden was de impact van het biologisch systeem hoger. Uit de betreffende analyse blijkt inderdaad dat waar het verschil tussen biologisch en gangbaar in $\mathrm{N}$-lekkage ( $\mathrm{N}$ verlies wordt op deze wijze niet in een LCA gebruikt en wordt hier een non-LCA impact genoemd) significant is als wordt gekeken naar de non-LCA impact per eenheid grondoppervlak, dit niet het geval is als het de non-LCA impact wordt bezien per eenheid product. Over het algemeen laten de resultaten zien dat biologische bedrijfssystemen een positieve impact hebben op het milieu per eenheid grondoppervlak, maar niet noodzakelijkerwijs per eenheid product. 
Het vergelijken van biologische en gangbare systemen op klimaateffecten is niet eenvoudig. Een belangrijke belemmering is dat het door optreden van allerlei verstrengelingen binnen productieketens lastig is om te duiden welk systeem nu lagere emissie geeft en wat de relatie is met de keuzes die binnen een productiesysteem worden gemaakt. Een vergelijking tussen biologische en gangbare bedrijven loopt dus tegen methodische hobbels aan.

Productiesystemen, zeker dierlijke productiesystemen zijn een aaneenschakeling van processen. De vergelijking van de footprint van eindproducten is lastig omdat deze vaak wordt bepaald door een serie aan keuzes in de bedrijfsvoering. In de plantaardige productie lijkt dat nog relatief eenvoudig, omdat het om één gewas of product gaat, maar ook daar is het gewas onderdeel is van een bouwplan. Bouwplannen van gangbare en biologische bedrijven zijn vaak verschillend wat betreft gewaskeuze en de bouwplan grootte in jaren. Daarnaast is de input van nutriënten en organische stof en soms de grondbewerking op geheel andere wijze georganiseerd, zoals bijvoorbeeld blijkt uit Gelfand et al., 2013. 


\section{A Non-LCA impacts per unit of land}

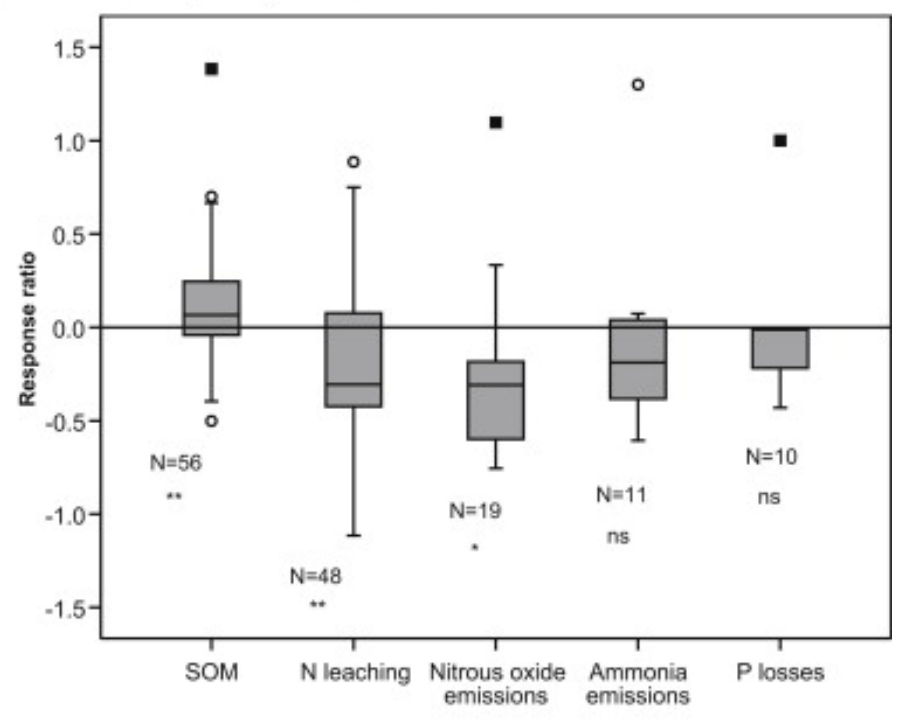

B Non-LCA impacts per unit of product

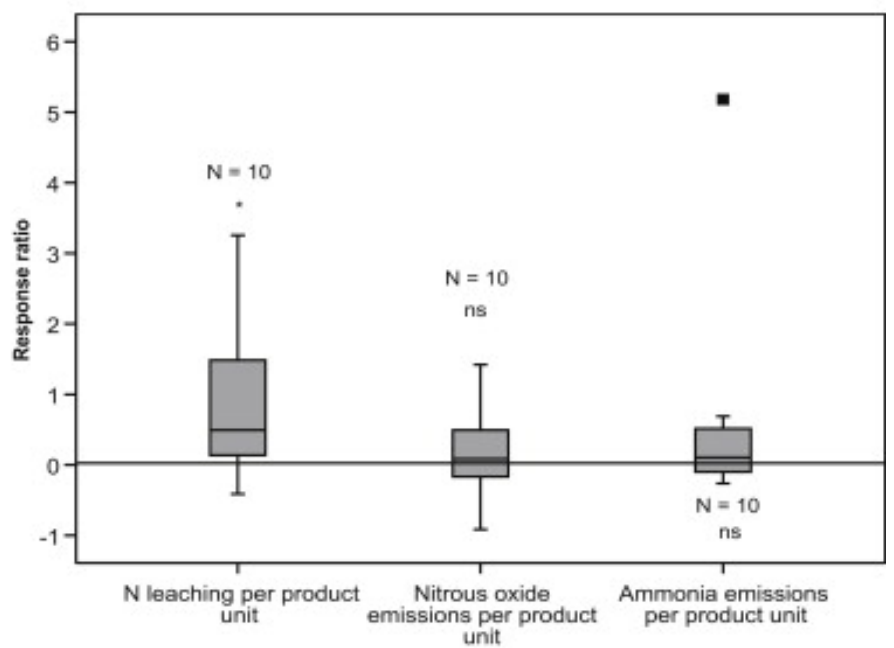

C LCA impacts per unit of product

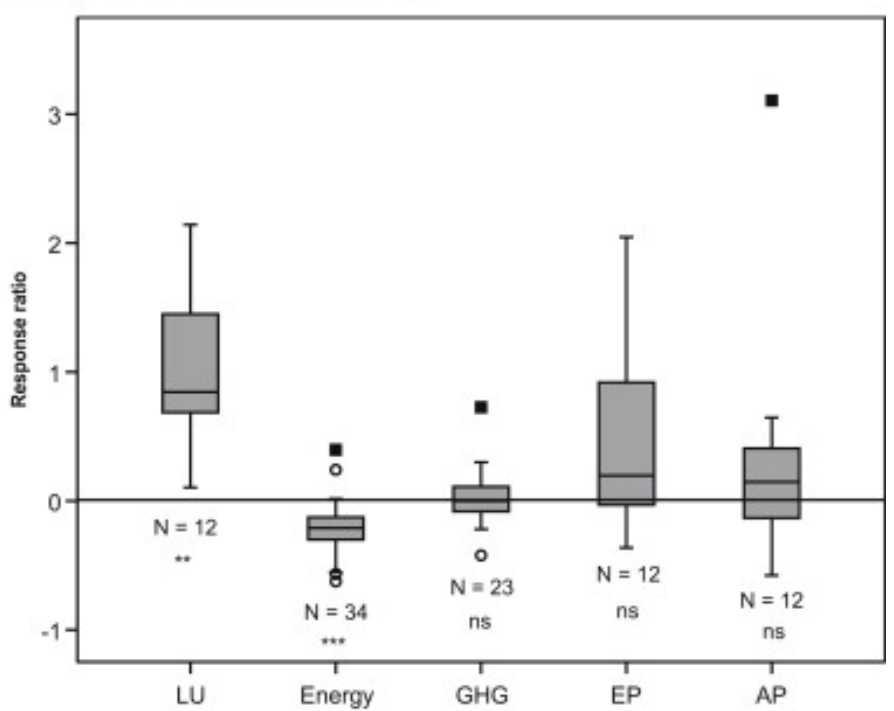

Figuur 3 De non-LCA response ratio uitgedrukt per eenheid land ( $\mathrm{A}$; soil organic matter (SOM), phosphorus ( $\mathrm{P}$ ) losses, nitrogen ( $\mathrm{N}$ ) leaching, nitrous oxide emissions and ammonia emissions ) en per eenheid product (B; nitrogen (N) leaching, nitrous oxide emissions and ammonia emissions) en de LCA waarde per eenheid product ( $C$; energy use, greenhouse gas emissions (GHG), acidification potential (AP), eutrophication potential (EP) and land use (LU)). Positieve waarden geven aan dat de biologische productiewijze een hogere impact heeft, bij negatieve waarden heeft de biologische sector juist een lagere impact. NS = niet significant, $* * * \mathrm{P}<0.001 ; * * \mathrm{P}<0.01 ; * \mathrm{P}<0.05$. Bron: (Tuomisto et al. 2012). 
In de veehouderij wordt de footprint van een product voor 35 tot $80 \%$ bepaald door de footprint van de gebruikte voeders (voor respectievelijk rundvee en éénmagige dieren als varkens en kippen). Zie Figuur 4.
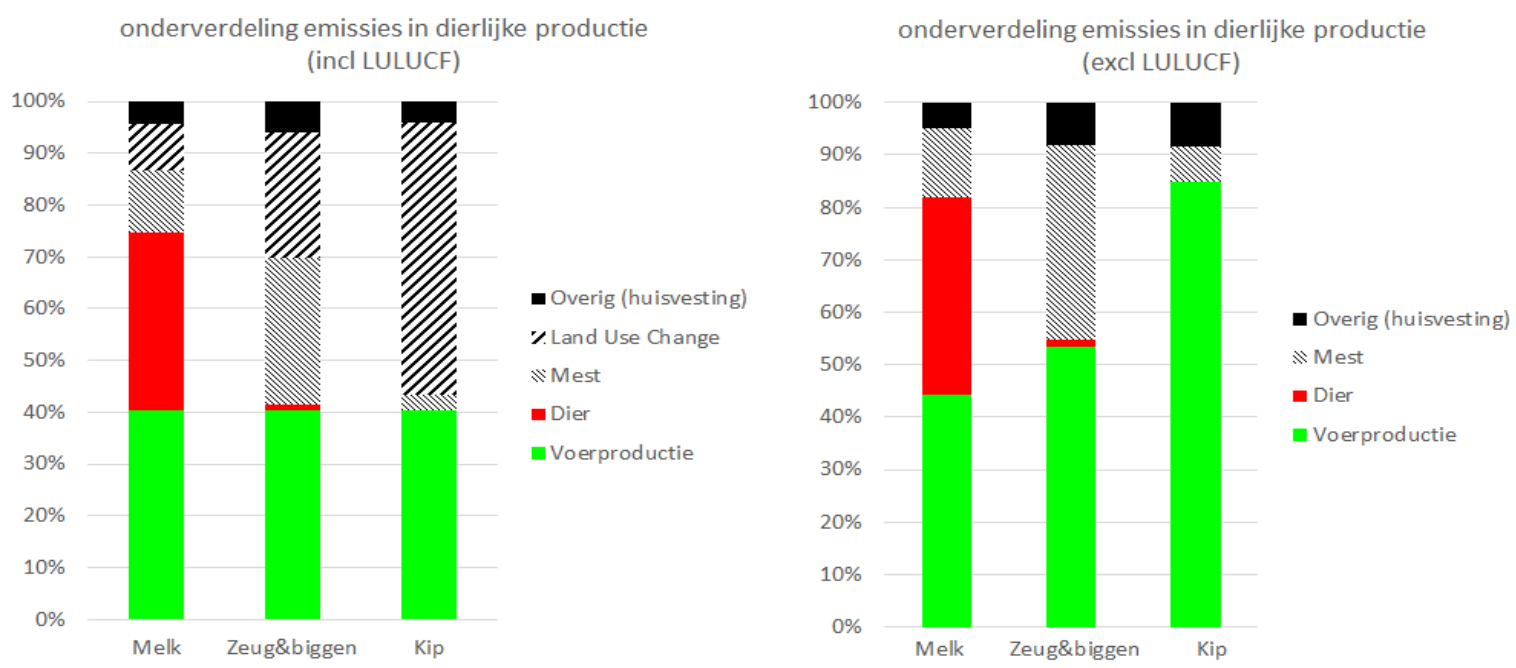

Figuur 4

Overzicht van de onderverdeling van emissies in dierlijke productie vanuit Feedprint (Vellinga 2012). Links met de emissies als gevolg van verandering in landgebruik (land use change) meegenomen, rechts is dat niet gedaan.

Als landgebruiksverandering door het gebruik van soja wordt meegenomen, stijgt dit aandeel nog (Figuur 4, links). De methodische problemen van de vergelijking van de plantaardige productie zijn hiervoor al benoemd. Daar komt in het dierlijke productiesysteem nog variatie bij als gevolg van keuze en herkomst (land) van de voeders en de aandelen ervan in een rantsoen, het gebruik van hulpmiddelen, zoals synthetische aminozuren e.d., de keuze van het stalsysteem en de bijbehorende wijze waarop wordt omgegaan met dierlijke mest, de plaats waar de dierlijke mest weer wordt ingezet als meststof, de mate van uitloop en bewegingsvrijheid en het ras van de dieren. Het rantsoen bepaalt weer voor een aanzienlijk deel de productiviteit van dieren. Bij een levenscyclus analyse is de dierlijke productie altijd de noemer in de berekening (emissies per kg product) en deze heeft dus ook zijn invloed op de emissies. Voor broeikasgassen is het niet relevant om de emissies per hectare weer te geven.

In de levenscyclus analyse (LCA) wordt vaak een hotspot analyse gemaakt. Deze identificeert de belangrijkste emissieposten van een product. Voor melk is de emissie van methaan de belangrijkste hotspot. Het is bekend dat de methaanemissie uit de pens van rundvee wordt bepaald door de keuze van de voedermiddelen en de totale voeropname. Er zijn echter geen dierproeven bekend waarbij een vergelijkende meting is gedaan van de methaanemissie van dieren bij een biologisch en een gangbaar rantsoen. Wel kunnen er berekeningen worden gedaan. Maar dat ligt buiten de scope van dit rapport. Bij gangbare varkenshouderij is de methaanemissie uit mestopslag nog een belangrijke hotspot, omdat (bijna) altijd wordt gewerkt met dunne mest, een combinatie van mest, urine en enig water. Bij biologische varkenshouderij wordt vaker gewerkt met stro of met een uitloop. Voor stromest en mest in een uitloop gelden andere emissiefactoren. 
Voor alle diergroepen is de emissie van de voederproductie van belang. Bij de éénmagige dieren wordt de emissie van de voerproductie deels bepaald door de teelt, maar ook voor een niet onaanzienlijk deel ook door transport en verwerking van primaire producten en bijproducten tot mengvoeders. Dat geldt ook voor de biologische veehouderij, sommige biologische grondstoffen worden van andere continenten gehaald omdat ze binnen Nederland of Europa niet verkrijgbaar zijn. De footprint van de primaire producten wordt grotendeels bepaald door de inputs, terwijl de footprint van de mengvoeders grotendeels wordt bepaald door alle processen na de primaire productie (verwerkende industrie, transport, mengvoer maken), zie Figuur 5.

Figur 5 Overzicht van de opbouw van de emissies van grondstoffen en mengvoer.

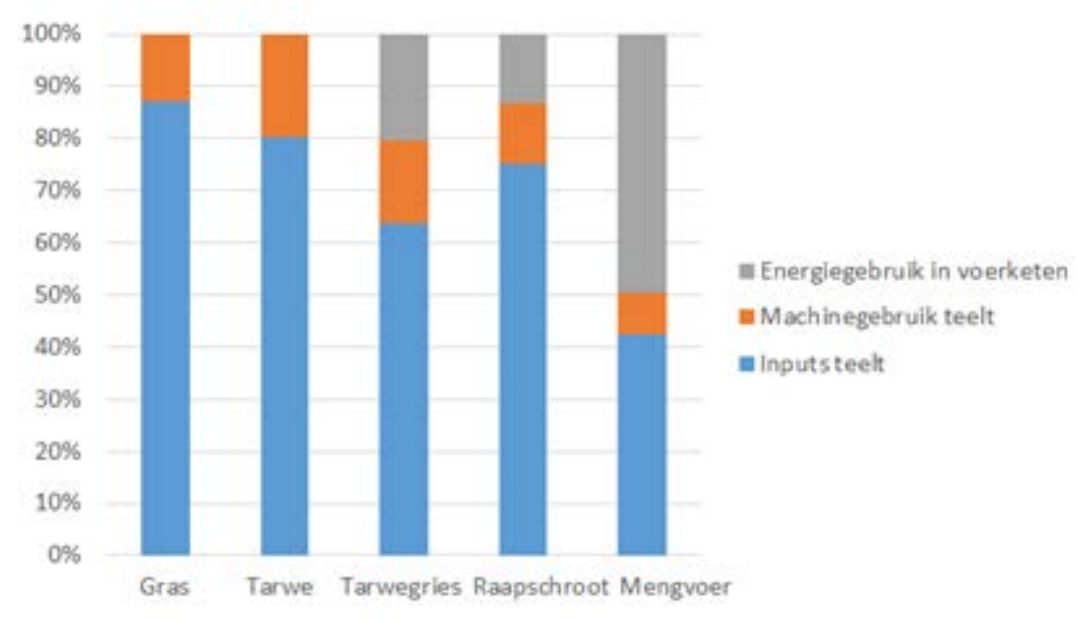

Opbouw emissies grondstoffen en mengvoer

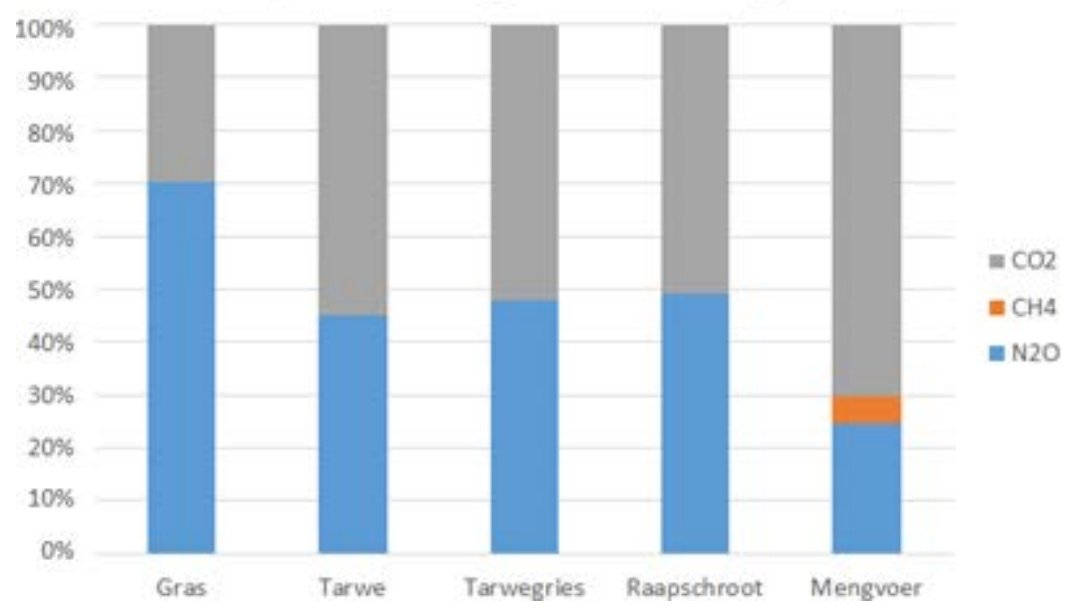

De inputs zijn opgebouwd uit lachgasemissies voor het gebruik van $\mathrm{N}$ houdende meststoffen en $\mathrm{CO} 2$ voor de productie van kunstmest en voor de productie en aanwending van kalkmeststoffen.

Om dus inzicht te verkrijgen in de verschillen tussen biologische en gangbare veehouderij, is het belangrijk eerst meer inzicht te krijgen in de opbouw van rantsoenen (inclusief gebruik van synthetische aminozuren) om op detailniveau de verschillen in emissies te kunnen verklaren: welk deel valt toe te schrijven aan de teelt, welk deel aan de rantsoensamenstelling en welk deel aan de herkomst van de grondstoffen. In de afgelopen jaren is er geen systematische en vergelijkende monitoring geweest van rantsoenen in de veehouderij. Eerdere studies (bijv. Bos et al. 2014) waren namelijk vaak gebaseerd op de situatie bij modelbedrijven, waar gras en mais op gangbare melkveehouderijen werd gevoerd en gras/klaver mengsels en mais op biologische melkveehouderijen. Wel kunnen er een aantal algemene uitspraken worden gedaan over rantsoenen.

De vastlegging van koolstof in organische stof in de bodem is weliswaar geen hotspot in de zin dat het een grote invloed heeft op de broeikasgasemissies per $\mathrm{kg}$ product, maar het is wel een belangrijk onderdeel van de teelt van producten. Daarom wordt naast de lachgasemissie ook de opbouw van organische stof in de bodem meer in detail beschouwd. 


\section{Resultaten}

\subsection{Primaire productie}

Hotspots

Als we de literatuur over de primaire productie raadplegen, blijkt er veel informatie beschikbaar te zijn over het bodemkoolstofgehalte (SOC) en de emissie van $\mathrm{N}_{2} \mathrm{O}$. Dit zijn echt hotspots, waar veel onderzoek naar gedaan is, waarschijnlijk ook omdat hier de grootste absolute waarden (emissies) worden verwacht. In Tabel 3 staan per sector de belangrijkste hotspots beschreven. Daarnaast zijn ook witte vlekken in de primaire productie en achterliggende keten benoemd. Deze zullen verderop in het rapport nader worden omschreven.

Tabel 3 Overzicht van de hotspots en de witte vlekken

\begin{tabular}{|l|l|l|}
\hline Sector & Hotspots & Witte vlekken \\
\hline $\begin{array}{l}\text { Plantaardige productie } \\
\text { (akkerbouw, tuinbouw) }\end{array}$ & $\begin{array}{l}\mathrm{N}_{2} \text { - emissie uit gebruik } \\
\text { kunstmest en dierlijke mest, } \\
\text { productie van kunstmest } \\
\text { Organische stofbalans en } \\
\text { organische stofgehalte bodem }\end{array}$ & $\begin{array}{l}\text { Onduidelijkheden in } \\
\text { achterliggende keten (o.a. } \\
\text { lagere omzetsnelheid in de } \\
\text { retail, verspilling) }\end{array}$ \\
\hline Herkauwers (runderen) & $\begin{array}{l}\text { Productie van methaan } \\
\text { (pensfermentatie, mestopslag), } \\
\text { verschillen in houderijsysteem } \\
\text { (weidegang vs. opstallen) }\end{array}$ & $\begin{array}{l}\text { verstrengeling met plantaardige } \\
\text { productie (eigen bedrijf, } \\
\text { aankoop voer), rantsoen, } \\
\text { onduidelijkheden in } \\
\text { achterliggende keten (o.a. } \\
\text { lagere omzetsnelheid in de } \\
\text { retail, verspilling) }\end{array}$ \\
\hline $\begin{array}{l}\text { Eenmagigen (varkens, } \\
\text { pluimvee) }\end{array}$ & $\begin{array}{l}\text { Emissies vanuit voerproductie } \\
\text { (lachgas en CO, van indirect } \\
\text { energieverbruik) }\end{array}$ & $\begin{array}{l}\text { Sourcing van biologische } \\
\text { voedermiddelen; EU eisen aan } \\
\text { biologisch eiwit; verstrengeling } \\
\text { met plantaardig bedrijf; } \\
\text { onduidelijkheden in } \\
\text { achterliggende keten (o.a. } \\
\text { lagere omzetsnelheid in de } \\
\text { retail, verspilling) }\end{array}$ \\
\hline
\end{tabular}

Productiviteit

Uit eerder onderzoek is duidelijk geworden dat over het algemeen de oogsten van gewassen lager liggen bij biologisch dan bij gangbare systemen: er is dus sprake van een grotere yield-gap bij biologisch. In een onderzoek waar 362 gewasopbrengsten werden geanalyseerd (de Ponti et al. 2012), bleek dat de biologische opbrengst $20 \%$ lager lag. Dat ging echter specifiek over gewasniveau, de auteurs verwachten dat op bedrijfs- en regionaal niveau de yield-gap nog groter zal zijn bij biologische systemen.

Een belangrijke studie (Seufert et al. 2012) laat zien dat in het algemeen biologische opbrengsten lager liggen dan conventionele, maar dat de verschillen voor een belangrijk deel door de context worden bepaald (Figuur 6). Van belang zijn in elk geval de karakteristieken van het systeem en de locatie. De verschillen varieerden van biologische oogsten die 5\% lager uitkwamen (rain-fed legumes $\&$ perennials on weakacidic to weak-alkaline soils), 13\% lager (wanneer de beste biologische praktijken gebruikt werden) tot $40 \%$ lagere opbrengsten voor granen. Gemiddeld was de opbrengst $34 \%$ lager voor biologische productiesystemen versus conventionele. Onder uitmuntende omstandigheden (inclusief management) kan volgens deze auteurs de opbrengst van biologisch de conventionele systemen benaderen. 


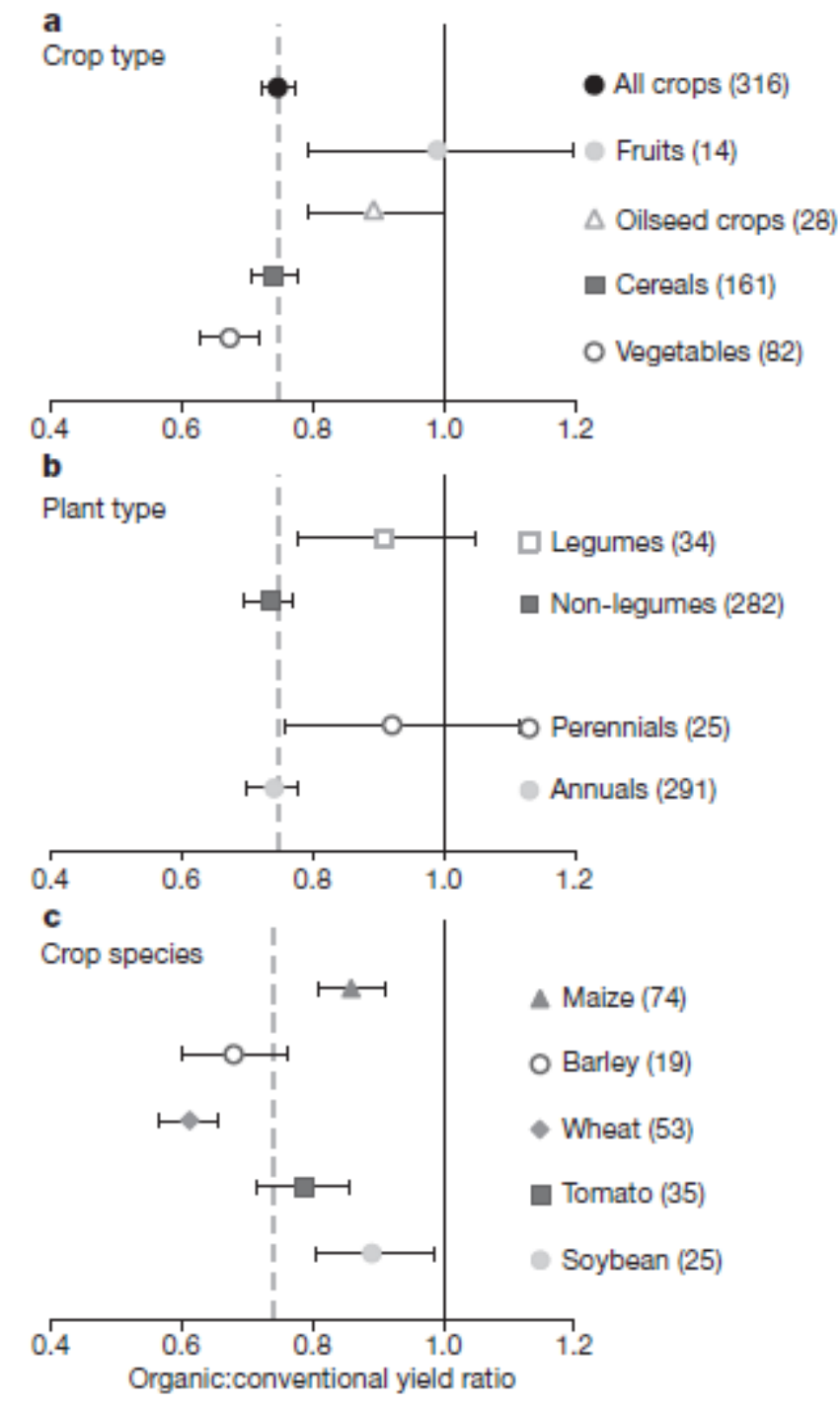

Figuur 6 De invloed van verschillende gewastypen (a), planten typen (b) en soorten (c) op de biologische/conventionele opbrengst ratio bij een $95 \%$ betrouwbaarheidsinterval. Alleen gewastypen en - soorten met tenminste 10 waarnemingen worden gerapporteerd. Het aantal waarnemingen per klasse staat tussen haakjes. De gestippelde lijn geeft het cumulatieve effect van het verschil over alle klassen heen (Seufert et al. 2012).

Ponisio et al. (Ponisio et al. 2015) claimen in een metastudie dat biologisch geteelde gewassen een $19 \%$ lagere oogstopbrengst laten zien dan conventioneel geteelde gewassen. Dit is een aanzienlijk lagere yield-gap als in eerdere studies werd gevonden. Voorts concluderen zij dat 2 landbouwkundige teelttechnieken, multi-cropping (meerdere gewassen in één jaar) en gewasrotatie, een positieve bijdrage leveren aan de verkleining van de yield-gap wanneer ze worden toegepast in biologische systemen. De auteurs denken voorts dat door extra bestedingen in toegepast onderzoek biologische bedrijfssystemen de yield-gap voor bepaalde gewassen of regio's kunnen wegnemen. Echter, het is maar de vraag of dit zo is. Het is uitermate lastig om landbouwsystemen te vergelijken op gewasniveau, mede omdat gewassen deel uitmaken van rotaties of complete regionale productieketens (Leifeld 2016). Voor biologische bedrijfssystemen geldt dat zij afhankelijk zijn van organische bronnen van nutriënten en daarom voor een belangrijk deel afhankelijk zijn van veehouderij en groenbemesters (gras-klaver mengsels, legumes en fodder crops). Biologisch geproduceerde gewassen hebben land nodig waar de nutriënten waarmee ze worden gevoed, worden geproduceerd. Dit land zou dus ook moeten worden meegerekend (Leifeld 2016). 


\section{Akkerbouw}

Er zijn zeer veel verschillende gewassen denkbaar, die elk hun eigen specifieke profiel hebben met betrekking tot de carbon footprint. Als we bijvoorbeeld kijken naar de carbon footprint van de productie van tarwe (zie Figuur 7), verdeeld in de verschillende broeikasgassen en hun bronnen, dan zien we dat met name de $\mathrm{N}_{2} \mathrm{O}$ emissie in het veld en de $\mathrm{N}_{2} \mathrm{O}$ afkomstig uit de kunstmest zogenaamde hotspots zijn (Brentrup \& Pallière, 2008).

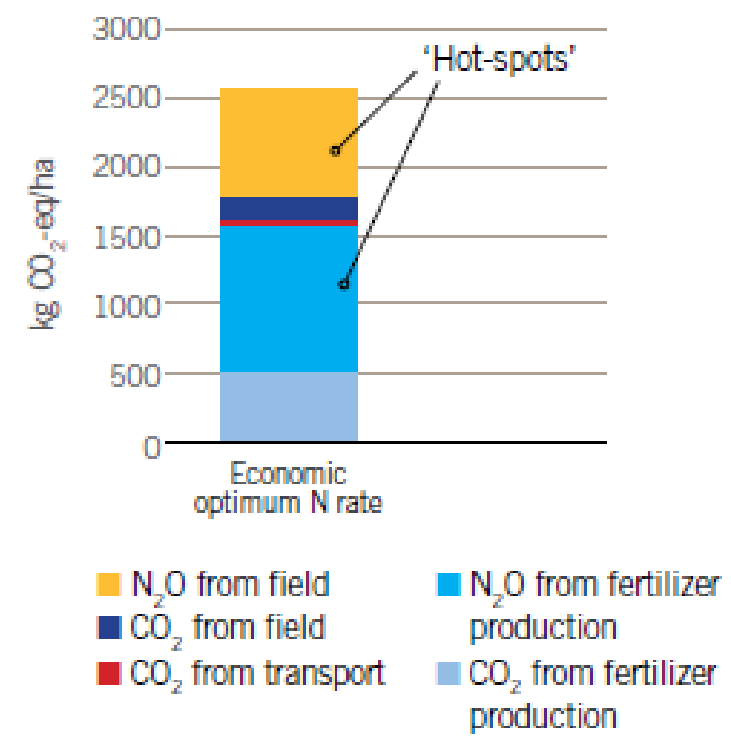

Figuur 7

De carbon footprint van tarwe productie, verdeeld in verschillende broeikasgassen en haar bronnen (Brentrup \& Pallière, 2008)

Naast de verschillen tussen gewassen, is er ook sprake van verschillen tussen teeltsystemen (biologisch vs. gangbaar). Uit een wetenschappelijke meta-analyse gebaseerd op 12 studies met jaarlijkse metingen bleek dat biologisch gebruikte gronden minder $\mathrm{N}_{2} \mathrm{O}$ emissie gaven dan conventioneel gebruikte gronden, om precies te zijn $492 \pm 160 \mathrm{~kg} \mathrm{CO}_{2}$ equivalent ha-1 $\mathrm{a}^{-1}$ minder (Skinner et al. 2014). Echter, de $\mathrm{N}_{2} \mathrm{O}$ emissies per eenheid geoogst product waren hoger $(41 \pm 34 \mathrm{~kg}$ $\mathrm{CO}_{2}$ equivalent $\mathrm{t}^{-1} \mathrm{DM}$ onder biologisch management (akkerbouw). Om dit te compenseren, moest het verschil in yield-gap tussen gangbaar en biologisch minder dan $17 \%$ zijn. Op dit moment is hiervan voor veel gewassen nog geen sprake (Skinner et al. 2014).

De overall prestaties van de biologische productie in relatie tot de vermindering van broeikasgasemissies zijn in Duitsland bestudeerd door middel van een case studie op 40 gangbare en 40 biologische bedrijven (Hülsbergen and Rahmann 2013), gedurende vijf jaar (2009 tot 2013). Deze vergelijking liet zien dat de biologische bedrijven een hogere nutriënten- en energie-efficiëntie hadden en een lagere broeikasgasemissie hadden (uitgedrukt in $\mathrm{CO}_{2}$ equivalent per producteenheid, voor melk en tarwe). Daarbij moet wel worden gesteld dat er meer variatie was bij biologische bedrijven dan bij de gangbare (Hülsbergen and Rahmann 2013).

Een studie uit Denemarken (Chirinda et al. 2010) vergeleek een jaar lang de lachgasemissie $\left(\mathrm{N}_{2} \mathrm{O}\right)$ vanuit de bodem van een conventioneel productiesysteem van wintertarwe met een drietal biologische systemen met verschillende hoogten van bemesting, aanwezigheid van vanggewassen en $\mathrm{N}_{2}-$ vastleggend gewas. Volgens de auteurs werd het conventionele systeem gekenmerkt door kortetermijn bodemvruchtbaarheidsdenken, terwijl bij de biologische systemen de langere termijn juist centraal stond. Hoewel men verschillende emissieniveaus waarnam tussen de verschillende seizoenen, verschilde de over het jaar gemeten lachgasemissie niet ondanks het feit dat er in de biologische systemen minder stikstof werd aangevoerd (Chirinda et al. 2010). 
Zoals al eerder aangegeven bij "Methodiek en beperkingen" is het vaak lastig om conventionele en biologische gewassystemen 1 op 1 te vergelijken. Dit blijkt ook uit een Zweedse review-artikel (Kirchmann et al. 2016). Deze auteurs geven aan dat als er een beperkt aantal indicatoren worden genomen (bijv. opbrengst, vastlegging van koolstof, biologische diversiteit en stikstof lekkage) er serieuze tekortkomingen kunnen optreden in vergelijkende analyses, die de uitkomsten enorm verzwakken. Een probleem dat volgens deze auteurs vaak optreedt is dat het experimenteel ontwerp van de proef vaak een onevenwichtigheid vertoont, en dat indicatoren die dienen voor een vergelijking vaak onvoldoende doordacht worden gebruikt. Zij geven aan dat het voor het voorkomen van misinterpretaties nodig is om vooraf een aantal stringente criteria te hanteren om zo de wetenschappelijke kwaliteit van de studies te verbeteren: 1. De initiële vruchtbaarheid van de bodem moet gelijk zijn tussen locaties, bedrijven of regio's die worden vergeleken; 2 . de vergelijking moet plaatsvinden bij hetzelfde gewas / dezelfde rotatie, en liefst zonder complicerende factoren; 3 . De hoeveelheden koolstof en nutriënten die worden aangevoerd in een systeem moeten worden gekwantificeerd. Het review liet verder aan de hand van een literatuuranalyse zien dat systemen die gebaseerd zijn op goede agronomische praktijken superieur zijn boven biologische systemen wat betreft opbrengst, nutriëntenlekkage, broeikasgasemissie en biodiversiteitsbehoud (Kirchmann et al., 2016).

Figuur 8 Links de gasvormige emissies uitgedrukt in $\mathrm{CO}_{2}$ equivalenten voor wintertarwe. Gemiddelde organische tarweoogst was $3 \mathrm{Mg} \mathrm{ha}^{-1}$ en gemiddelde gangbare oogst 5.6 $\mathrm{Mg} \mathrm{ha}^{-1}$. Rechts de stikstoflekkage uit een lange veldproef met biologische en gangbare teelt. De gemiddelde oogst was $2.0 \mathrm{Mg}$ ha-1 voor biologische rotatie en 6.1 $\mathrm{Mg} \mathrm{ha}^{-1}$ voor gangbaar. Op cit. (Kirchmann et al. 2016)
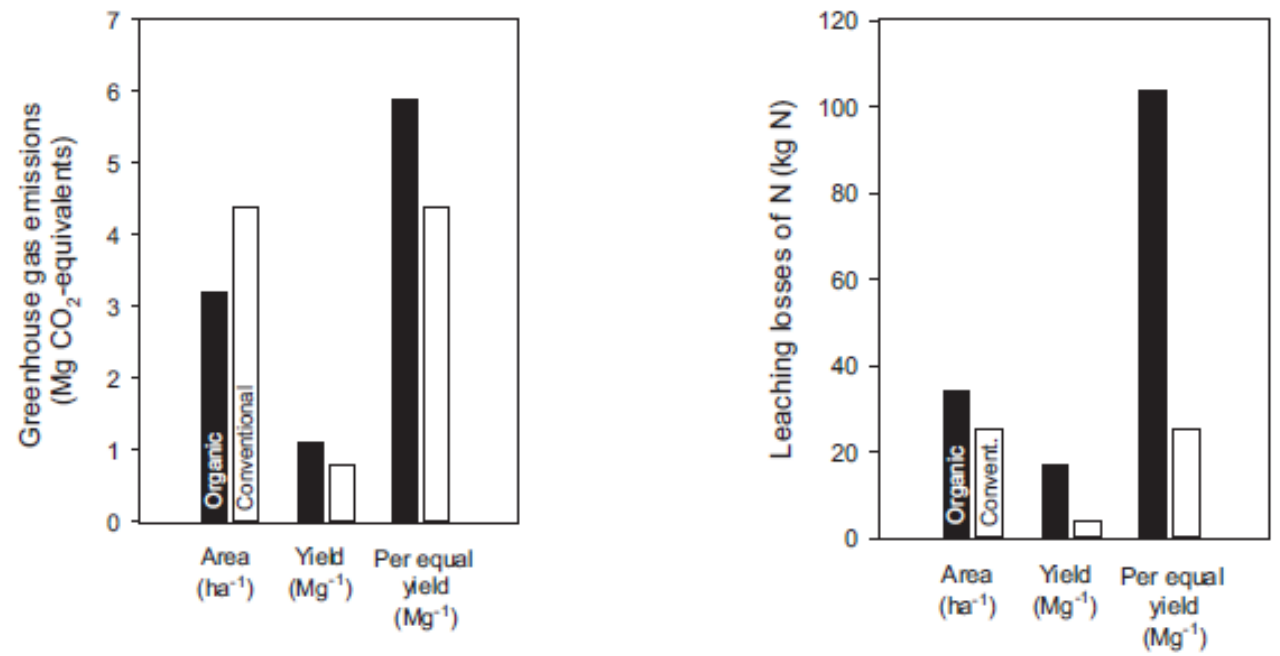

Organische stof in de bodem

Van biologische bedrijfssystemen wordt vaak gedacht dat de bodemvruchtbaarheid (Soil Organic Matter, SOM) wordt vergroot en dat daarmee een belangrijke bijdrage wordt geleverd aan de vastlegging van atmosferische $\mathrm{CO}_{2}$. Hoewel veel veldexperimenten een dergelijk positief effect suggereren, komen auteurs die de daadwerkelijke data van 68 van deze experimenten hebben onderzocht tot de conclusie dat de meeste studies niet ontworpen waren om koolstofvastlegging te meten (Leifeld and Fuhrer 2010). Veel studies misten een heldere baseline/nulsituatie,

koolstofmetingen of waren onduidelijk over de vergeleken systemen voor biologische en conventionele productie. Vaak werden hierdoor aan biologische productie kwalificaties toegedicht die niet terecht waren. De overall analyse liet zien dat het bodemkoolstofgehalte (SOC, een belangrijk onderdeel van de SOM) in biologische systemen jaarlijks relatief met $2.2 \%$ toenam, waar bij conventionele systemen geen verschil meetbaar was. Echter, het gebeurde vaak dat de hoeveelheid biologische mest in het biologisch systeem de hoeveelheid in het gangbare systeem overtrof of dat de gewasrotatie verschilde. Kortom: dit leidde er volgens deze auteurs toe dat een verhoogd bodemkoolstofgehalte vaak niet terug te voeren was op de biologische handelswijze, maar meer op de veel grotere inzet van organische bemesting (Leifeld et al. 2010).

Een concreet voorbeeld van een studie waarin dergelijke fouten zijn gemaakt is de studie van Gattinger et al. (Gattinger et al. 2012). In deze studie werden datasets van 74 studies onderzocht en men vond dat gronden met biologische bewerking significant hogere C-voorraden, concentraties en Copbouw hadden vergeleken met gangbare bewerkte gronden. Echter, volgens Leifeld et al. (Leifeld et al. 2013) vergaten deze auteurs dat de bodems op biologische bedrijven, gemiddeld, veel hogere externe C-inputs hadden (mest, compost) dan de gangbaar bewerkte gronden. Een stijging van 
bodemkoolstof (hetzij in een biologisch of in een gangbaar systeem) is niet alleen een netto overgang van $\mathrm{CO} 2$ vanuit de lucht, maar ook de aanvoer van $\mathrm{C}$ uit bestaande organische stof (mest, compost of andere biomassa) van de ene plek naar de andere. Kortom: de interpretatie van Gattinger et al. (Gattinger et al. 2012) vinden zij misleidend.

Het blijkt bovendien uitermate lastig te zijn om met organische mestsoorten ervoor te zorgen dat Cvoorraden in de bodem worden opgebouwd, zonder het klimaateffect daarvan teniet te doen via de productie van extra $\mathrm{N}_{2} \mathrm{O}$. Dit blijkt uit een Nederlandse studie (Bos et al. 2017). De modelberekeningen van de auteurs gaven aan dat, op rotatieniveau, gewasresten, runderdrijfmest en compost significant kunnen bijdragen aan de toename van SOC (200-450 kg C ha-1 jaar-1), en dat de bijdrage van varkensdrijfmest en vanggewassen relatief beperkt waren (20-50 kg C ha-1 jaar-1). Het gebruik van compost leidde vervolgens tot de minste $\mathrm{N}_{2} \mathrm{O}$-emissie, waarbij wel moet worden opgemerkt dat mogelijk $\mathrm{N}_{2} \mathrm{O}$ vrijgekomen is bij het produceren van de compost (Bos et al. 2017). Het is sowieso belangrijk om, als $\mathrm{N}_{2} \mathrm{O}$ emissies worden gerapporteerd en emissiefactoren worden geschat, meer rekening te houden met het effect van de lengte van de studie op de respons van $\mathrm{N}_{2} \mathrm{O}$ (Albanito et al. 2017).

Er kunnen een aantal aanvullende kanttekeningen worden gemaakt bij het idee dat een verhoging van SOC goed is voor het klimaat (Ten Berge et al. 2017). Deze auteurs komen tot de conclusie dat de verhoging van SOC als een klimaatmaatregel erg beperkt is door: 1. De beperkende beschikbaarheid van C-bronnen, 2. $\mathrm{N}_{2} \mathrm{O}$ emissies die samenhangen met de meeste praktijken die SOC bevorderen, en 3. vanuit bedrijfseconomisch perspectief. Daarbovenop moet worden gesteld dat 4. alleen koolstof met een oorsprong in de extra primaire productie en koolstof waarvan verbranding wordt voorkomen bijdraagt aan klimaatmitigatie. Daarnaast draagt het gebruik van organische biomassa voor bioenergie (in plaats van fossiele brandstof) meer bij aan klimaatmitigatie dan het opbrengen op het land (Powlson et al. 2011). Tot slot stellen de auteurs dat winsten die worden gemaakt voor wat betreft SOC snel kunnen worden verloren als met de landbouwtechnieken worden gestopt, terwijl $\mathrm{N}_{2} \mathrm{O}$ emissies irreversibel zijn (Ten Berge et al. 2017). Vanuit bodemkundig oogpunt is de agronomische winst en de bijdrage aan de bescherming van de bodem wel aan te bevelen.

Het goed nadenken over rotaties als geheel is belangrijk. Uit een langjarige proef op zandgrond (Ten Berge et al. 2016) in Polen (ca. 30 meetjaren) bleek dat je heel veel (50-90\% op gehele rotatie) kunstmest $\mathrm{N}$ kunt uitsparen door 1,5 jaar grasklaver in de rotatie op te nemen (Pikula et al. 2016). Weliswaar is er dan in 1 van de 4 jaar sprake van een voeder (grasklaver i.p.v. mais) dat niet gelijkwaardig is in energie, maar voor de overige 3 jaar is er een gelijke gewasopbrengst van biologisch in vergelijkbaar met gangbaar? Een aandachtspunt is wel dat onbekend is hoe generiek deze uitkomsten zijn.

Soms zien we ook onverwachte uitkomsten. Uit een onderzoek (Hijbeek et al. 2017) waarin 20 langetermijn experimenten in Europa nader werden onderzocht bleek dat organische inputs en SOM niet noodzakelijkerwijs leiden tot hogere oogsten. Er bestaat geen simpele relatie tussen organische inputs en gewasgroei, was hun conclusie.

Tuinbouw

Wat betreft de tuinbouw is een mooi overzicht gemaakt in een Nederlandse studie (Bos et al. 2014). Uit deze analyse blijkt dat over het algemeen de biologische productie een hogere productie van broeikasgassen per eenheid product laat zien als de gangbare productie. De achterliggende oorzaak hiervan is volgens deze auteurs dat er in verband met de mechanische onkruidbestrijding extra veel gebruik gemaakt moet worden van diesel gestookte tractoren. Zie voor een compleet overzicht Figuur 9. 


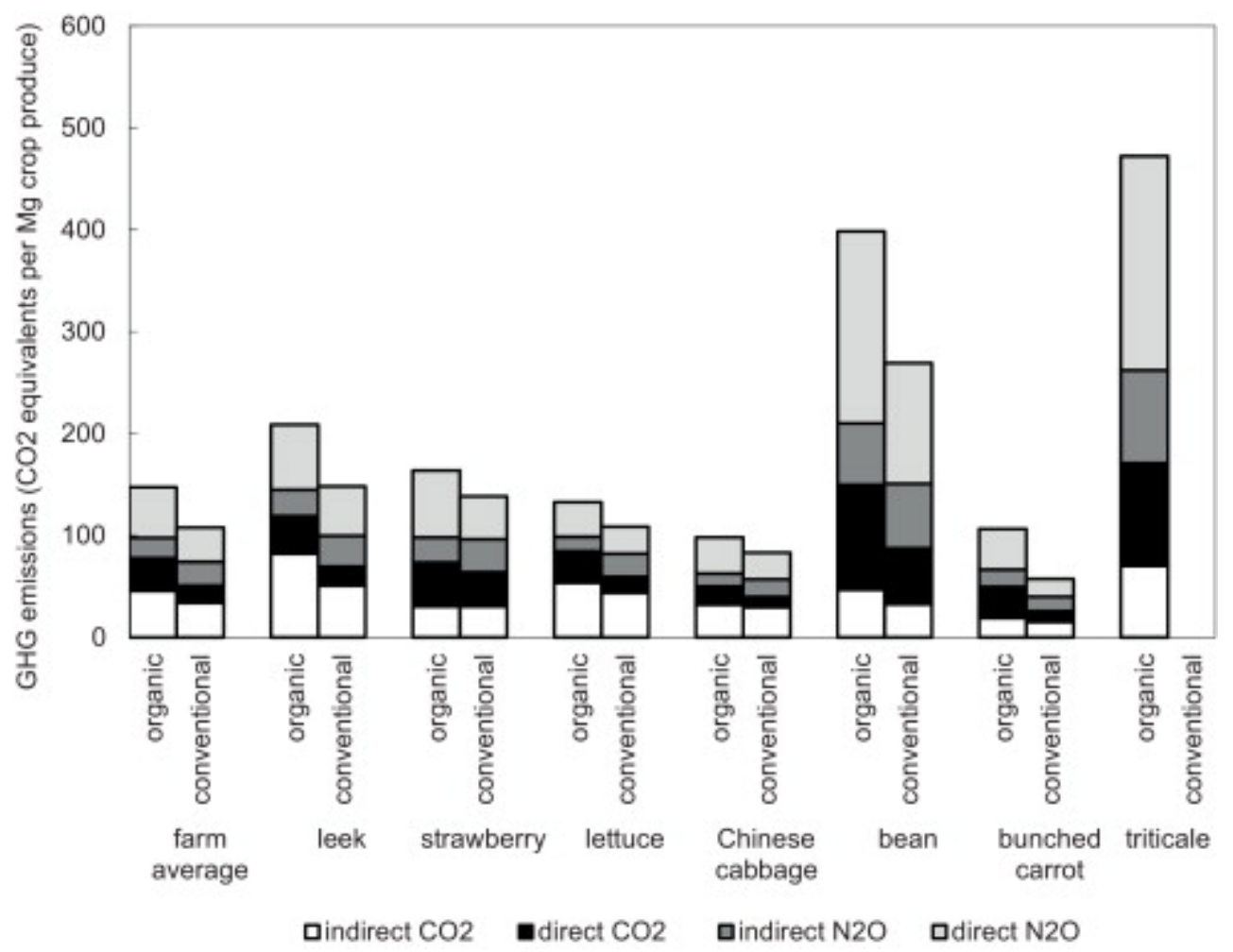

Figuur 9 De emissie van broeikasgassen (in $\mathrm{CO}_{2}$ eq. per $\mathrm{Mg}$ geproduceerd gewas) op biologische en gangbare tuinbouwbedrijven (Bos et al. 2014).

Melkveehouderij

Pensfermentatie is de grootste bron van methaan, in totaal wordt ca. $45 \%$ van de broeikasgasemissies op melkveebedrijven hierdoor veroorzaakt (Hietala et al. 2015). Mestopslagen zijn, na pensfermentatie, de grootste bron van methaanemissies in de melkveehouderij. Op sommige locaties in het bedrijfssysteem wordt ook $\mathrm{N}_{2} \mathrm{O}$ uitgestoten, zie onderstaande figuur (Figuur 10, bron: (Owen and Silver 2015). In deze figuur geeft de dikte van de pijlen de relatieve emissie aan.

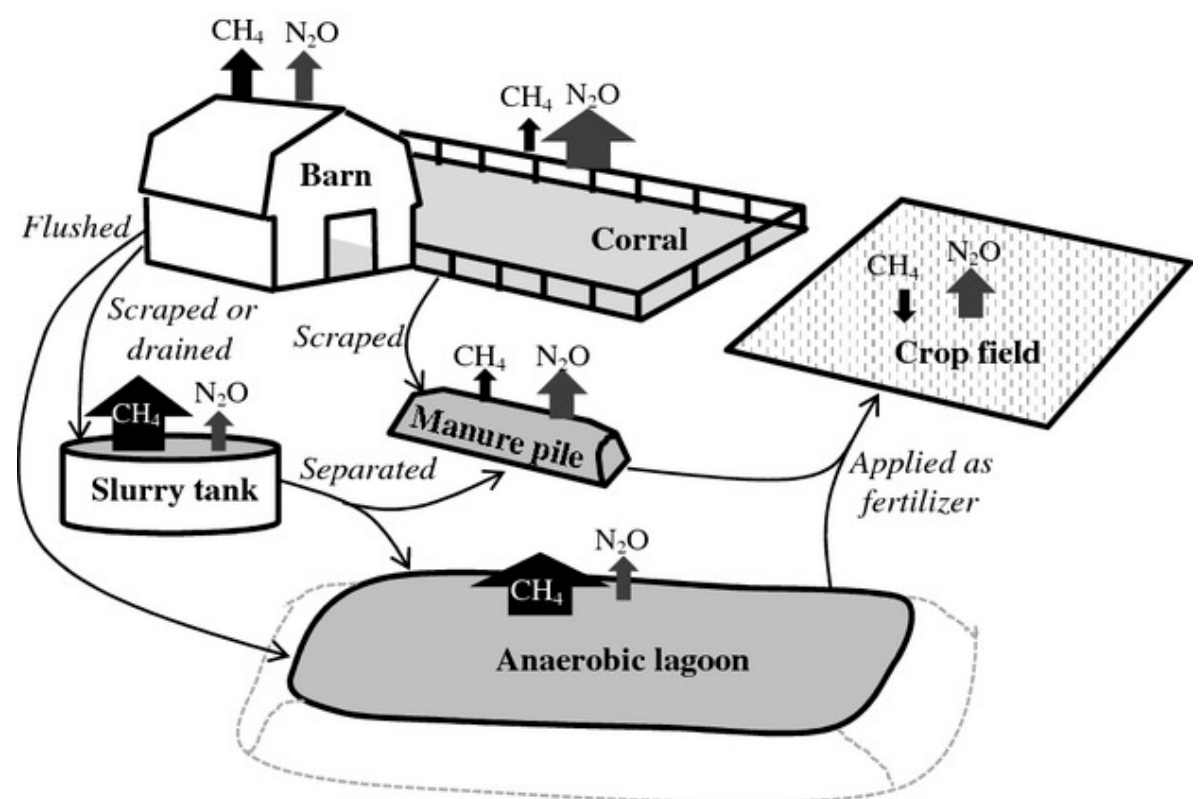

Figuur 10 Bronnen van $\mathrm{CH}_{4}$ en $\mathrm{N}_{2} \mathrm{O}$ op melkveebedrijven (Owen and Silver 2015). 
Het is interessant om te zien of er verschillen zijn tussen mest van biologische en conventionele melkveehouderijen. Uit een studie die werd gedaan met behulp van tracer gas is gekeken naar de productie van broeikasgasemissies vanuit al dan niet afgedekte mestopslagen voor biologische en gangbare melkveesystemen (Sneath et al. 2006). Gedurende 12 maanden werden niet afgedekte systemen doorgemeten en men vond emissiewaarden liggen tussen 14.4 tot $49.6 \mathrm{~g} \mathrm{C} \mathrm{m}^{-3} \mathrm{~d}^{-1}$ voor gangbare systemen en 12.4 tot $42.3 \mathrm{~g} \mathrm{C} \mathrm{m}^{-3} \mathrm{~d}^{-1}$ voor biologische met gemiddelde $\mathrm{CH} 4$ emissie waarden van 35 en $26 \mathrm{~g} \mathrm{C} \mathrm{m}^{-3} \mathrm{~d}^{-1}$. In beide bedrijfssystemen waren de $\mathrm{N}_{2} \mathrm{O}$ emissies bijna nul (Sneath et al. 2006). Door grote variatie in de resultaten konden geen significante verschillen tussen de beide bedrijfssystemen worden aangetoond.

In een Nederlandse studie (Bikker et al. 2013) wordt de excretie van stikstof en fosfaat van biologisch gehouden varkens, pluimvee en melkvee berekend en vergeleken met gangbaar gehouden dieren onder de Nederlandse context. De door deze auteurs berekende N- en P-excretie per melkkoe per jaar was bij biologisch gehouden melkvee circa $12 \%$ lager dan bij gangbaar gehouden melkvee. De berekende excretie per $\mathrm{kg}$ melk was circa $12 \%$ hoger bij biologische melkkoeien. Deze verschillen kunnen volgens Bikker et al. verklaard worden door de lagere melkproductie en daarmee samenhangend de lagere VEM-behoefte en berekende voeropname en mineralenexcretie per koe. Voor een betere onderbouwing van de excretie zou het gewenst zijn dat meer gegevens betreffende ruwvoerverbruik en -samenstelling worden vastgelegd, met name op biologische bedrijven. Op basis van de nu beschikbare informatie concluderen zij met redelijke zekerheid dat er tussen biologisch en gangbaar gehouden melkkoeien geen grote verschillen in excretie per dier zijn, anders dan die veroorzaakt door het melkproductieniveau.

In een metastudie (Gomiero et al. 2011) is uitgebreid gekeken naar het energieverbruik vanuit de melkveehouderij, zowel voor biologisch als gangbaar. Uit onderstaande tabel blijkt dat in de meeste studies het energiegebruik per hectare en per ton product vaak lager was voor biologische melkveehouderij.

Tabel 4 Overzicht van de energie consumptie in gangbare en biologische melkveehouderijen Et al. 2011)

\begin{tabular}{|c|c|c|c|c|c|c|}
\hline \multirow[b]{2}{*}{ Studie } & \multicolumn{3}{|c|}{ Energieconsumptie GJ ha-1 } & \multicolumn{3}{|c|}{ nergieconsumptie $\mathrm{GJ} \mathrm{t}^{-1}$} \\
\hline & Gangbaar & Biologisch & $\begin{array}{l}\text { Biologisch } \\
\text { als } \\
\% \text { van } \\
\text { gangbaar. }\end{array}$ & Gangbaar & Biologisch & $\begin{array}{l}\text { Biologisch } \\
\text { als } \\
\% \text { van } \\
\text { gangbaar. }\end{array}$ \\
\hline Cederberg \& Mattsson (1998) & 22.2 & 17.2 & 77 & 2.85 & 2.41 & 85 \\
\hline Refsgaard et al. (1998) & - & - & - & 3.34 & $2.16 / 2.88$ & $75 / 87$ \\
\hline Cederberg \& Mattsson (1998) in Haas et al. (2001) & - & - & - & 2.85 & 2.4 & 92 \\
\hline Haas et al. (1995) in Haas et al. (2001) & 19.4 & 6.8 & 35 & - & - & - \\
\hline Haas et al. (2001) & 19.1 & 5.9 & 31 & 2.7 & 1.2 & 46 \\
\hline Thomassen et al. (2008)* & & & & 4.4 & 2.17 & 51 \\
\hline Müller-Lindenlauf et al. (2010) - Grassland & - & - & - & 1.52 & 1.2 & 79 \\
\hline Müller-Lindenlauf et al. (2010) - Mix farm & - & - & - & 1.17 & 1.32 & 113 \\
\hline
\end{tabular}

(*) inclusief indirecte kosten. 
In de zeer uitgebreide studie van Bos et al. (Bos et al. 2014) is gekeken naar de broeikasgasemissies (in $\mathrm{CO}_{2}$ equivalenten per $\mathrm{Mg}$ melk) op biologische en gangbare melkveebedrijven. De resultaten van deze studie staan in onderstaande figuur (Figuur 11). De verschillen die ontstaan zijn met name het resultaat van de verschillen tussen directe en indirecte $\mathrm{N}_{2} \mathrm{O}$ emissies, en van de indirecte $\mathrm{CO}_{2}$ emissie als gevolg van ontbossing voor soja-productie. Als wordt gekeken naar de productie van broeikasgassen per kg melk zit gangbare melk dus hoger dan biologisch. Voor de productie van broeikasgassen per $\mathrm{kg}$ melk lagen biologische systemen 5-10\% lager dan gangbaar, qua energieverbruik lag biologisch ongeveer $25 \%$ lager (Bos et al. 2014).

Figuur 11 De emissie intensiteit per kg melk voor verschillende bedrijfssystemen. Bron: Bos et

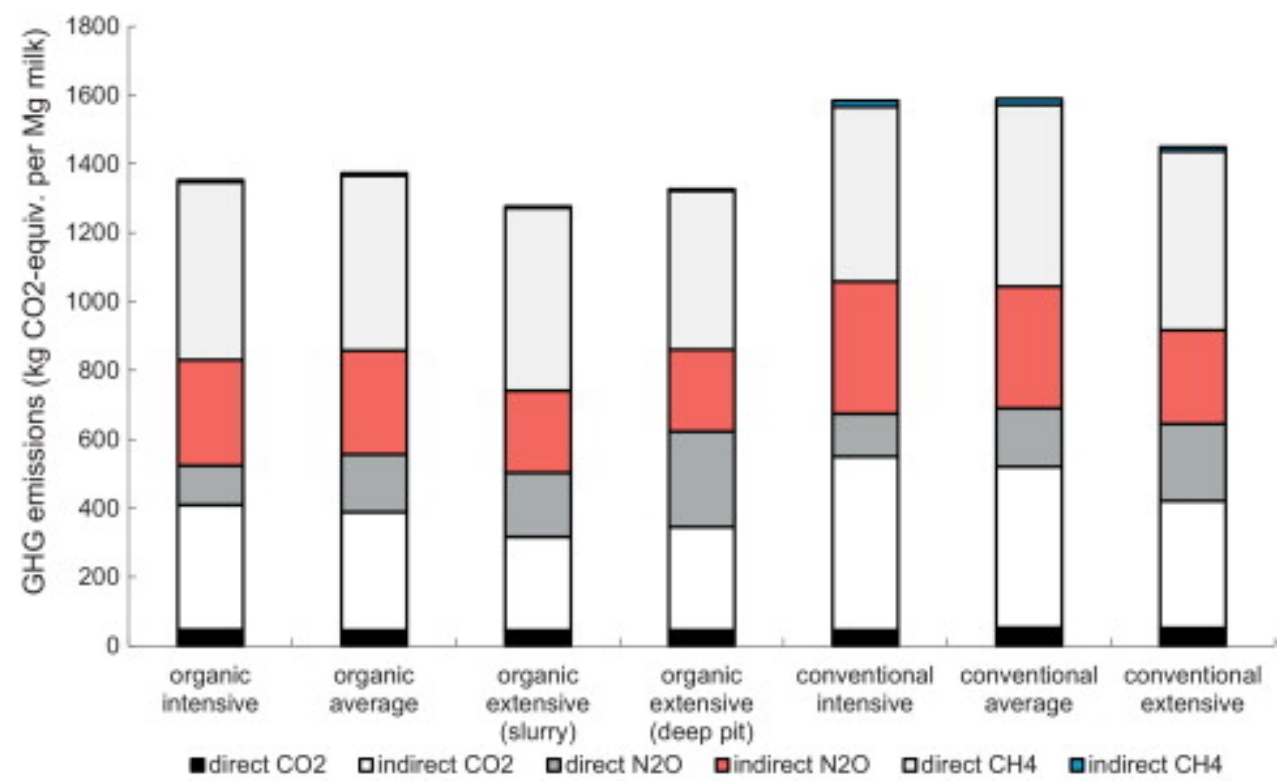

al., 2014.

In een studie van Basset-Mens et al. (Basset-Mens et al. 2009) wordt het belang van het kiezen van een goede functionele eenheid (Functional Unit) benadrukt, omdat dit van grote invloed kan zijn voor de interpretatie. Dit verschil treedt bijvoorbeeld al op als de impact van de productie van melk per landoppervlak (bijvoorbeeld per hectare) wordt vergeleken met de productie per ton product. De auteurs komen tot de conclusie dat de milieu impact uitgedrukt in kg melk moet worden vermenigvuldigd met de melkproductie per koe, de veedichtheid, en de ratio tussen de beschikbare ruwvoer op het bedrijf en van elders, om de impact per hectare te krijgen. Dit betekent dat een hoog aantal kilo's $\mathrm{CO}_{2}$ equivalenten per ha niet noodzakelijk leidt tot een lager aantal $\mathrm{kg} \mathrm{CO}_{2}$ per kg melk, en vice versa. De auteurs benoemen dat beleidsmakers daarom heel voorzichtig moeten zijn met de directe interpretatie van resultaten vanuit levenscyclusanalyses (LCA's).

In een Zweedse studie werd de gemiddelde carbon footprint berekend voor zowel gangbare als biologische bedrijven. Men vond dat de carbon footprint een klein beetje lager lag voor biologische bedrijven (die een lagere melkgift per koe hebben, maar meer vlees per kg melk produceren), maar als een $90 \%$ allocatie factor wordt gebruikt is de carbon footprint van biologische melkveebedrijven juist wat hoger vergeleken met hoogproductieve gangbare melkveebedrijven (Flysjö et al. 2012). De allocatiefactor wordt in de nieuwste berekeningen gebaseerd op de netto energiebehoefte voor groei van dieren en voor melk (IDF, 2016).

Een Duitse studie beschrijft een onderzoek naar de biologische melkveehouderij aldaar (MüllerLindenlauf et al. 2018). Men vond dat Duitsland binnen de biologische sector er zowel traditioneel gemengde bedrijven zijn met een relatief lage melkgift van $6000 \mathrm{~kg}$ per koe, maar dat er ook hooggespecialiseerde biologische bedrijven zijn met meer dan $9000 \mathrm{~kg}$ per koe. Binnen de biologische sector worden specialisatie en intensivering steeds meer kritisch besproken vanwege de verwachte negatieve effecten. In de studie vergeleek men de potentiele milieu impact van vier verschillende typen biologische melkveebedrijven, gebaseerd op een analyse van 27 bedrijven, die werden gerubriceerd door het percentage grasland op het bedrijf en de voerintensiteit. Men keek naar energieverbruik, klimaat impact, vraag naar land, emissies van ammoniak, nitraatuitspoeling, behoud van bodemvruchtbaarheid, biodiversiteit, dierwelzijn en melkkwaliteit. Men vond dat high-input bedrijven voordelen lieten zien in de impact categorieën klimaatimpact en vraag naar land. Daar 
tegenover stonden positieve milieu effecten van low-input bedrijven in de categorieën dierenwelzijn, melkkwaliteit en ammoniakverliezen. Alles overziend kwamen de auteurs tot de conclusie dat het bedrijfstype "low-input gemengd bedrijf" het beste milieukundige resultaat had. Dit ondersteunde hun hypothese dat bedrijven die werken volgens de traditionele biologische principes minder negatieve milieu impact met zich meebrengen, ook binnen de hele biologische sector. De auteurs geven wel aan dat meer onderzoek nodig is om de door hun gebruikte methodologie voor het vergelijken van dierwelzijn en melkkwaliteit te bevestigen en dat de resultaten van het alleen kijken naar de klassieke categorieën van milieu impact (energie consumptie en klimaat impact) kan leiden tot andere resultaten dan de bestudering van een meer complex systeem van voors en tegens (Müller-Lindenlauf et al. 2018).

Aan de hand van een rekenmodel werd op 12 conventionele en 12 biologische bedrijven in Zuid- en West-Duitsland gekeken hoe energie- en broeikasgasemissies van gangbaar en biologisch zich verhielden (Hülsbergen and Rahmann 2013). De broeikasgassen op biologische bedrijven waren $933 \mathrm{~g}$ $\mathrm{CO}_{2}$ eq $(\mathrm{kg} \mathrm{ECM})^{-1} \mathrm{GHG}$, tegenover $1076 \mathrm{~g} \mathrm{CO}_{2}$ eq $(\mathrm{kg} \mathrm{ECM})^{-1}$ op gangbare bedrijven. Belangrijke bronnen van broeikasgasemissie zijn de energie- gerelateerde emissies ( $17 \%$ van de totale emissie), methaanemissies door het vee, en $\mathrm{N}_{2} \mathrm{O}$-emissies uit de ruwvoerproductie (Hülsbergen and Rahmann 2013). De gemiddelde input van fossiele energie per $\mathrm{kg}$ energie-gecorrigeerde melk (ECM) was 2.27 MJ $(\mathrm{kg} \mathrm{ECM})^{-1}$ voor de biologische en $2.47 \mathrm{MJ}(\mathrm{kg} \mathrm{ECM})^{-1}$ voor de gangbare bedrijven. De grootste energie input werd veroorzaakt door de ruwvoerproductie, met name door de aankoop van ruwvoer. Ook het melken en het fokken van het jongvee vereist veel energie.

Tabel 5 Broeikasgasemissie per dier in de biologische en gangbare melkveehouderij in Duitsland (Hülsbergen and Rahmann 2013)

\begin{tabular}{|l|l|l|l|}
\hline & & Biologisch & Gangbaar \\
\hline Koeien & $\mathrm{Kg} \mathrm{CO}_{2}$ eq / dier & 2422 & 2581 \\
\hline Kalveren & $\mathrm{Kg} \mathrm{CO}_{2}$ eq / dier & 115 & 122 \\
\hline
\end{tabular}

Dezelfde auteurs vergeleken ook 12 biologische en 12 gangbare bedrijven in Midden-Duitsland. Ook daar vond men dat de totale emissie van biologische bedrijven per kg melk gemiddeld lager lag dan die van gangbare bedrijven ( 1006 vs. $1067 \mathrm{~g} \mathrm{CO}_{2} \mathrm{eq}$ ). Een globaal overzicht van de verschillen wordt gegeven in Figuur 12.

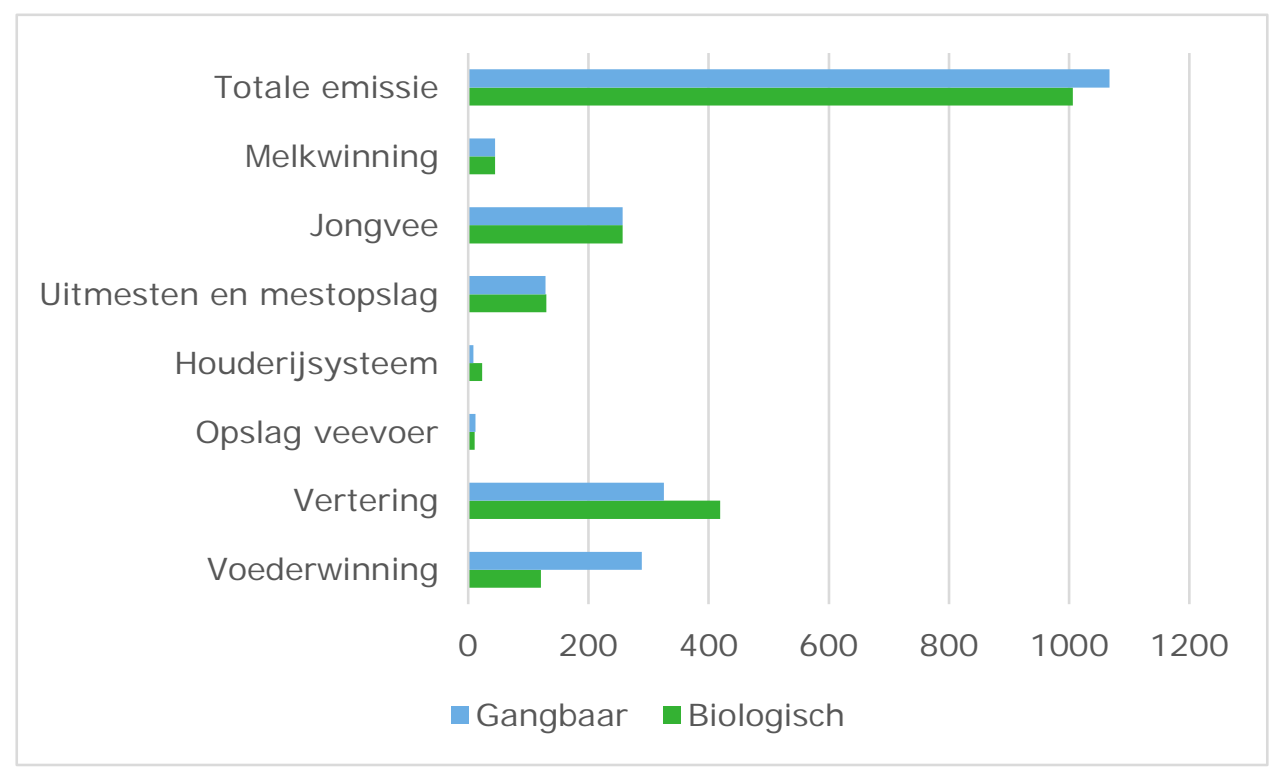

Figuur 12 Overzicht van de gemiddelde broeikasgasemissie per $\mathrm{kg}$ melk (in $\mathrm{g} \mathrm{CO}_{2}$ eq $(\mathrm{kg} \mathrm{ECM}$ $\left.{ }^{1}\right)$ ) voor 12 biologische en 12 gangbare melkveehouderijen in Midden-Duitsland (Hülsbergen and Rahmann 2013).

Varkenshouderij

Uit een studie waarin werd gekeken naar de verschillen in broeikasgasproducties (GHG-emissies) in de varkensketen in 4 verschillende landen (Denemarken, Engeland, Duitsland en Nederland) werden ook verschillende productiesystemen onderzocht (Kool et al. 2009). Hieruit bleek dat gangbare productie van varkensvlees een carbon footprint had van 3.5-3.7 $\mathrm{kg} \mathrm{CO}$ eq. per $\mathrm{kg}$ varkensvlees (vers vlees na 
de slachterij). De carbon footprint van biologisch varkensvlees lag tussen de 4.0 (Denemarken) en 5.0 (Duitsland) $\mathrm{kg} \mathrm{CO} 2$ eq. per $\mathrm{kg}$. Het landgebruik voor de productie van varkensvlees bleek een groot effect op de broeikasgasemissies te hebben. Hotspots zijn het groeien van het gewas voor de voerproductie, het transport van die gewassen, de verwerking van die gewassen, transport van grondstoffen en het mixen van veevoer). Dit draagt voor ruwweg 50-60\% bij aan de carbon footprint van zowel de gangbare als de biologische productie van varkensvlees. In de meeste systemen is vervolgens de emissie van methaan het tweede belangrijke punt (12-17\%). In systemen waarin uitloop wordt geïncorporeerd, zoals bij biologische productie in Denemarken en Engeland, zijn vervolgens de daarbij horende emissies het op twee na belangrijkste punt. De auteurs vonden de volgende belangrijkste mitigatieopties:

- Mestvergisting, waardoor de methaanemissies vanuit de mestopslag worden verminderd en broeikasgasproductie door elektriciteitsproductie vanuit fossiele bronnen wordt voorkomen;

- De voederconversie verlagen, hierdoor neemt de hoeveelheid voer en $\mathrm{N}$ per eenheid geproduceerd varkensvlees af;

- Het gebruik van natte co-producten in het veevoer;

- Slacht efficiëntie verder verbeteren en bijproducten uit de varkensvleesketen beter benutten;

- Kleine reducties in broeikasgasemissie (1-3\%) kunnen worden bereikt door bijvoorbeeld het afdekken van mestsilo's.

Als wordt gekeken naar de uitkomsten van de vergelijking worden de volgende getallen gevonden (Tabel 6):

Tabel 6 De carbon footprint van verschillende varkensvleessystemen in $\mathrm{kg} \mathrm{CO}_{2}$ eq. per kilogram vers varkensvlees na slachterij (Kool et al. 2009).

\begin{tabular}{lll} 
Land & Gangbaar & Biologisch \\
\hline Nederland & 3.6 & 4.3 \\
\hline Engeland & 3.5 & 4.4 \\
\hline Duitsland & 3.7 & 5.0 \\
\hline Denemarken & 3.5 & 4.0 \\
\hline
\end{tabular}

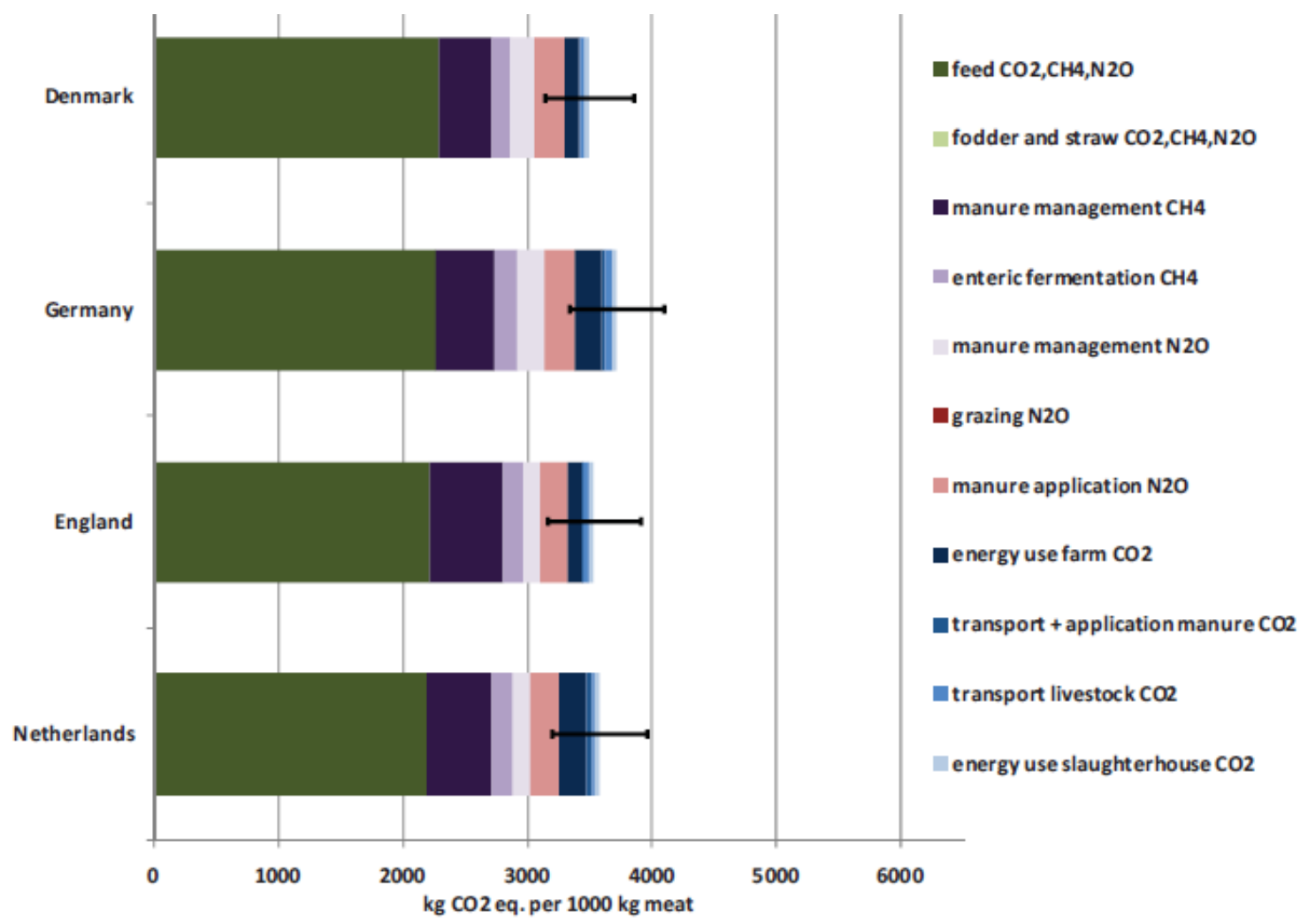

Figuur 13a De carbon footprint per $1000 \mathrm{~kg}$ gangbaar varkensvlees (vers vlees in de slachterij), (Kool et al. 2009) 


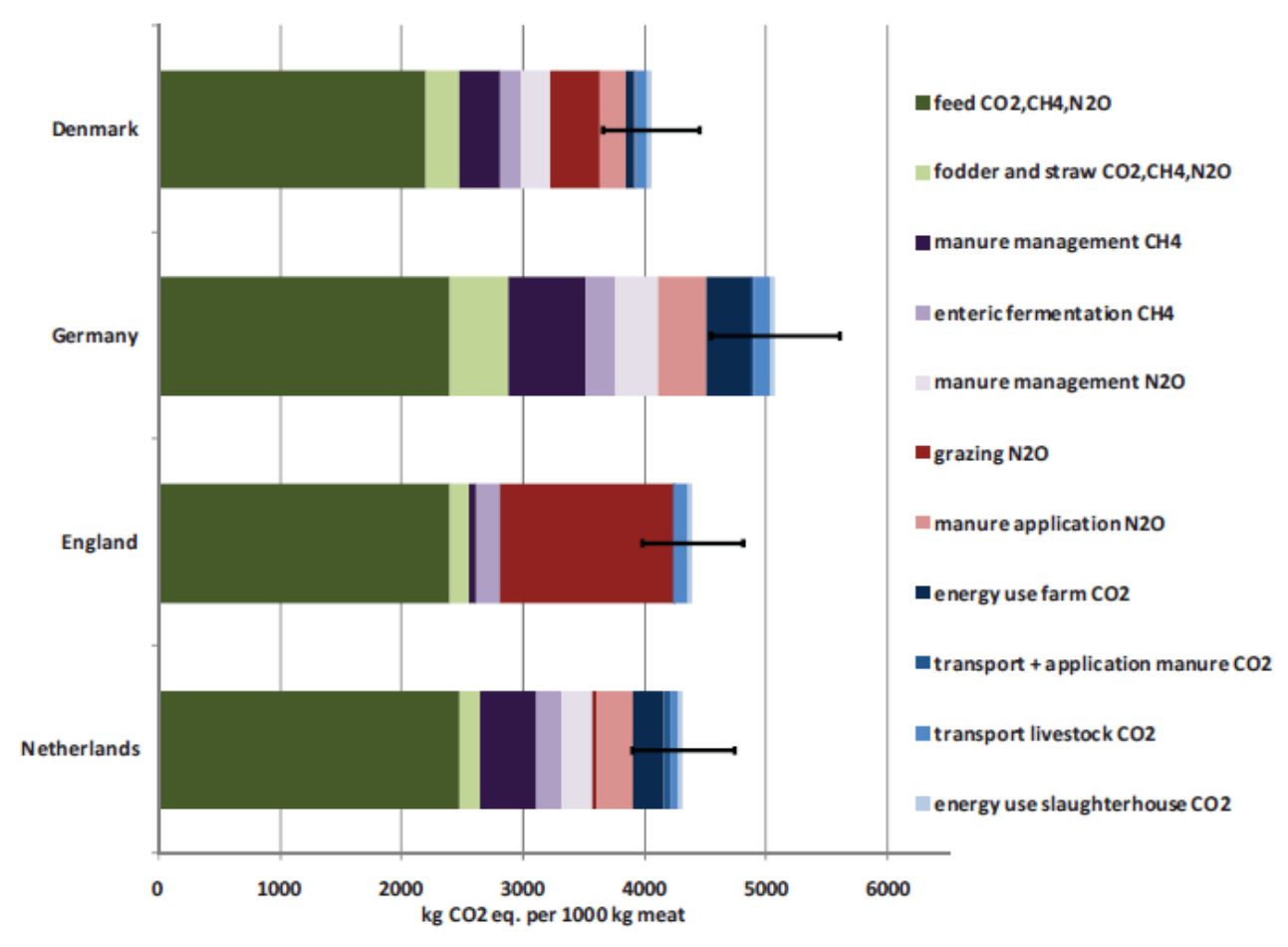

Figuur 13b De carbon footprint per $1000 \mathrm{~kg}$ biologisch varkensvlees (vers vlees in de slachterij), (Kool et al. 2009)

De auteurs geven aan dat, ondanks de verschillen tussen de vier landen in de tabel, de verschillen veelal niet statistisch significant zijn. Alleen het verschil tussen de hoogste carbon footprint waarde (Duitsland) en die met de laagste (Denemarken) kan als vrijwel zeker worden geclassificeerd. In Nederland en Duitsland is de carbon footprint van biologisch varkensvlees met meer dan $90 \%$ betrouwbaarheid hoger dan voor gangbaar varkensvlees (Kool et al. 2009).

Uit het eerdergenoemde rapport van Bikker et al. (Bikker et al. 2013) blijkt dat ten opzichte van gangbaar gehouden dieren de berekende $\mathrm{N}$ - en P-excretie per dier per jaar circa $25 \%$ hoger zijn bij biologisch gehouden vleesvarkens en respectievelijk circa 60 en 75\% hoger voor biologisch gehouden zeugen met bijbehorende biggen. De belangrijkste oorzaken zijn een slechtere voederconversie bij biologische vleesvarkens (minder efficiënte omzetting van voer in vlees), een hoger voerverbruik van biggen en zeugen en hogere $\mathrm{N}$ - en P-gehalten in het voer doordat geen gebruik gemaakt wordt van fytase en synthetische aminozuren.

In een Franse studie (Dourmad et al. 2014) werd de milieu impact in vijf landen (Denemarken, Nederland, Spanje, Frankrijk en Duitsland) berekend op het boerenbedrijf en uitgedrukt in de impact per kg varkensvlees levend gewicht (LW) en per hectare landgebruik. De bedrijfssystemen werden gecategoriseerd in gangbaar, aangepast gangbaar (met slechts kleine aanpassingen om vleeskwaliteit, dierwelzijn of milieu impact te verbeteren), traditioneel en biologisch. Traditionele bedrijven gebruikten erg dikke, langzaam groeiende rassen en mestten hun mestvarkens meestal buiten af. In Tabel 7 wordt een overzicht gegeven van de verschillende systemen en hun impact per $\mathrm{kg} L W$. We zien dat in het algemeen de meeste indicatoren een lagere ongewenste impact laten zien voor gangbare dan voor de alternatieve systemen. Specifiek het gebruik van stro leidde op biologische en traditionele bedrijven tot een hogere impact voor klimaatverandering (Dourmad et al. 2014). 


\begin{tabular}{|l|l|l|l|l|}
\hline & Gangbaar & $\begin{array}{l}\text { Aangepast } \\
\text { gangbaar }\end{array}$ & Traditioneel & Biologisch \\
\hline $\begin{array}{l}\text { Klimaatverandering } \\
\text { (kg CO2-eq/ kg LW) }\end{array}$ & 2.3 & 13 & 54 & 4 \\
\hline $\begin{array}{l}\text { Verzuring } \\
\text { (g SO2-eq / kg LW) }\end{array}$ & 44.0 & 5 & 79 & -16 \\
\hline $\begin{array}{l}\text { Eutrofiering } \\
\text { (g PO4-eq) }\end{array}$ & 18.5 & 0 & 23 & 29 \\
\hline Energiegebruik (MJ) & 16.2 & 2 & 50 & 11 \\
\hline Landgebruik $\left.\mathbf{( m}^{\mathbf{2}}\right)$ & 4.1 & 16 & 156 & 121 \\
\hline
\end{tabular}

Pluimveehouderij: vleeskuikens en leghennen

In het Verenigd Koninkrijk is een uitgebreide studie naar vleeskuikens uitgevoerd (Leinonen et al. 2012a), waarin een levenscyclusanalyse (LCA) werd uitgevoerd naar de milieubelasting per $1000 \mathrm{~kg}$ verwacht bruikbaar karkasgewicht tussen een gangbaar systeem, een systeem met vrije uitloop en een biologisch productiesysteem. Uit dit onderzoek bleek doordat bij vrije uitloop en biologisch de lengte van de productiecyclus groter was, de voederconsumptie en mestproductie per dier hoger waren. Dit veroorzaakte aanzienlijke verschillen (Tabel 8). De belangrijkste milieubelasting lag in de productie, het transport en het verwerkingsproces van het veevoer. Men vond dat $65-81 \%$ van het primaire energiegebruik en $71-72 \%$ van het broeikasgaseffect werden veroorzaakt door deze processen. Het gebruik van olie en gas op de boerderij was de tweede belangrijk hotspot (12-25\%), gevolgd door elektriciteitsverbruik. Direct gebruik van gas, olie en elektriciteit waren hoger bij vrije uitloop en biologische productiesystemen. Mest draagt het meeste bij aan verzuring en eutrofiering. Door op deze wijze te kijken naar hotspots wordt het volgens de auteurs gemakkelijker om mitigatie te bewerkstelligen (Leinonen et al. 2012a).

Tabel 8 Milieubelasting per vleeskuikenhouderijsysteem in het Verenigd Koninkrijk per 1000 kg karkasgewicht. Aangepast vanuit (Leinonen et al. 2012a)

\begin{tabular}{llll}
\hline & Gangbaar & Vrije uitloop & Biologisch \\
\hline Primair energie gebruik (GJ) & 25.37 & 25.65 & 40.34 \\
\hline $\begin{array}{l}\text { Global Warming Potential (per 1,000 kg } \\
\mathrm{CO}_{2} \text { equivalent) }\end{array}$ & 4.41 & 5.13 & 5.66 \\
\hline $\begin{array}{l}\text { Eutrofiërings potentieel (kg PO} \\
\text { equivalent) }\end{array}$ & 20.31 & 24.26 & 47.66 \\
\hline Verzuringspotentieel (kg SO 2 equivalent) & 46.75 & 59.73 & 91.55
\end{tabular}

Een zelfde soort analyse hebben deze auteurs ook uitgevoerd voor 4 veelgebruikte eierproductiesystemen in de UK: 1. kooi, 2. scharrel, 3. vrije uitloop en 4. biologisch (Leinonen et al. 2012b). Uit de analyse bleek dat het aantal dieren dat nodig was om 1000 eieren te produceren het hoogste was in het biologisch systeem en het kleinste in de kooien. Deze verschillen bepalen ook zeer de milieu impact tussen systemen. Productie, verwerking en transport van veevoer waren ook hier de hotspots: ze zijn verantwoordelijk voor 54-75\% van het primaire energiegebruik en $64-72 \%$ van de bijdrage aan het broeikasgaseffect (global warming potential, GWP). Het verbruik van elektriciteit op het primaire bedrijf (gebruikt voor ventilatie, automatische voersystemen en verlichting) was de een na grootste post van het primair energieverbruik (16-38\%). Het gebruik van gas en olie (gebruikt voor verwarming in de broederij en het verbranden van dode hennen) zorgde voor 7-14\% van het energieverbruik. Mest had de grootste impact op verzuring en vermesting. In onderstaande tabel (Tabel 9) wordt een overzicht gepresenteerd van de milieuprestaties van verschillende houderijsystemen. 


\begin{tabular}{lllll}
\hline & Kooi & Scharrel & Vrije uitloop & Biologisch \\
\hline Primair energie gebruik (GJ) & 16.88 & 22.20 & 18.78 & 26.41 \\
\hline $\begin{array}{l}\text { Global Warming Potential (per 1,000 kg CO} \\
\text { equivalent) }\end{array}$ & 2.92 & 3.45 & 3.38 & 3.42 \\
\hline Eutrofierings potentieel (kg PO 4 equivalent) & 18.47 & 20.32 & 22.03 & 37.61 \\
\hline $\begin{array}{l}\text { Verzuringspotentieel (kg SO} 2 \text { equivalent) } \\
\text { ( }\end{array}$ & 53.14 & 59.43 & 64.13 & 91.63
\end{tabular}

Dit onderzoek bevestigt in feite de eerdere conclusie vanuit Nederlands onderzoek dat de ban op kooisystemen in de Europese Unie leidt tot een toename van de bijdrage aan het broeikasgaseffect (Global Warming Potential), verzuring en landbezetting (Dekker et al. 2011).

Uit het rapport van Bikker et al. (Bikker et al. 2013) blijkt dat de N- en P-excretie per dier per jaar van biologisch gehouden leghennen respectievelijk 22 en $17 \%$ hoger zijn dan in gangbare scharrelsystemen en 35 en $26 \%$ hoger dan in gangbare verrijkte kooi /kolonie gehouden leghennen. De verschillen in excretie tussen gangbaar en biologisch gehouden dieren worden veroorzaakt door de slechtere voerconversie en de hogere $\mathrm{N}$ - en $\mathrm{P}$-gehalten in het voer bij biologisch gehouden dieren. De $\mathrm{N}$ - en P-excretie per vleeskuikenplaats per jaar van biologisch gehouden vleeskuikens zijn in vergelijking met gangbaar gehouden vleeskuikens respectievelijk 62 en 105\% hoger. De verschillen in excretie tussen gangbare en biologische vleeskuikens worden veroorzaakt door de lagere groei en slechtere voerconversie en door de hogere $\mathrm{N}$ - en P-gehalten in het voer bij biologisch gehouden dieren. De lagere groei en hogere voerconversie wordt met name veroorzaakt doordat in de biologische sector een ander type kuiken wordt gebruikt.

Een additioneel probleem is dat vanaf december 2017 het gebruik van niet-biologische eiwitbronnen in voeders voor biologisch pluimvee in de EU niet is toegestaan, evenals het gebruik van synthetische aminozuren. Concreet betekent dit dat het benodigde aminozuur methionine (Met) op andere wijze wordt ingevuld. Dit blijkt uitermate lastig (van Krimpen et al. 2016). Omdat verdunning van de beschikbare energie, gekoppeld aan een gelijkwaardige reductie in andere nutriënten, kan leiden tot het voldoen aan het $100 \%$ biologische dieet, zullen de hennen meer voeder moeten consumeren om in hun nutriënten behoefte te voorzien. Er zijn volgens de auteurs wel enkele mogelijkheden, maar als wordt gekeken naar praktische en economische oplossing en tevens de issues qua footprint, is de lijst opties wel erg beperkt. 


\subsection{Post-harvest verschillen tussen gangbaar en biologisch}

Er is een analyse per ketenstap gemaakt om de verschillen tussen gangbaar en biologisch nader in beeld te brengen. Deze analyse wordt hieronder nader beschreven:

\subsubsection{Ketenstappen}

\section{Verwerking}

Wanneer volumes van biologische producten zo veel kleiner zijn dat ze minder efficiënt worden verwerkt, zou dat leiden tot een hogere impact op het klimaat. Dit komt op dit moment zeker voor, maar uit de literatuur blijkt niet welke mate en ook niet hoe groot de verschillen tussen de verschillende producten zijn. De impact van de verwerking is dus een zogenaamde witte vlek. Belangrijk is wel om te melden dat het hier om een tijdelijk probleem kan gaan: als de gebruikte volumes biologische producten toenemen kan de efficiëntie ook toenemen.

\section{Zuivel}

De lagere efficiëntie is in ieder geval niet waarschijnlijk voor biologische zuivel. In Nederland wordt ook biologische zuivel in zulke grote hoeveelheden verwerkt dat het net zo efficiënt gaat als bij gangbare zuivel. Waarschijnlijk wordt het zelfs met exact dezelfde installaties gedaan (bijvoorbeeld bij Arla en bij FrieslandCampina). De verschillen tussen 50 zuivelfabrieken in de VS bleken daarnaast al zeer groot (Thoma et al. 2018), dus de technische standaard van een fabriek zal een groter verschil qua klimaatimpact veroorzaken dan het verschil tussen biologisch en gangbaar. Voor consumptiemelk is het verschil in verwerking tussen gangbaar en biologisch wel uitgezocht (Ziesemer 2007), maar dit is juist een weinig bewerkt product. Het is zelfs mogelijk dat onbewerkte producten door mensen in hun eigen ovens en fornuizen minder efficiënt tot dezelfde bewerkte staat worden gebracht dan in grote fabrieken, zie bijvoorbeeld (Schmidt Rivera et al. 2014; Braschkat et al. 2003).

\section{Bewerkte producten}

Ook voor de productie van intensief bewerkte producten zoals ingeblikte groenten, gedroogde producten, maaltijden, is de verwachting dat er een minimale schaalgrootte nodig is, om het economisch aantrekkelijk te maken (Ziesemer 2007). Volgens deze auteur zijn er weinig verschillen bij diverse producten; er wordt wel opgemerkt dat biologische producten over het algemeen minder bewerkt zijn. Minder bewerkte producten vergelijken met gewoon bewerkte producten zou echter onzuivere zijn. Het is mogelijk dat dat onbewerkte producten door mensen in hun eigen ovens en fornuizen minder efficiënt tot dezelfde bewerkte staat worden gebracht dan in grote fabrieken.

\section{Verpakking}

(Ziesemer 2007) geeft aan dat het de bedoeling is van biologische producten dat ze hun impact minimaliseren, zodat de kans groter is dat ze minder verpakking gebruiken (en minder bewerking). De vraag is echter of deze wijze van redeneren inderdaad klopt. (Ziesemer 2007) geeft ook aan dat de biologische sector zich net zo goed als de gangbare producenten aan de voedselveiligheidseisen houdt en voedselverliezen probeert te beperken door het gebruik van een goede verpakking.

\section{Opslag \& Transport}

Een van de aspecten die duidelijk kán verschillen is de logistiek van producten, maar ook hier zijn de verschillen in principe klein. Voor de meeste producten, met name de droge (niet-verse) producten en internationaal verhandelde, volgt de distributie hetzelfde model bij conventioneel en biologisch: via één distributiecentrum in Nederland. Daarnaast wordt een groot deel van biologische producten in de conventionele retail verkocht, en volgt het dus de gangbare distributiekanalen naar de retail. Ziesemer (2007) geeft aan dat biologische producten minder met energievragende methoden worden opgeslagen (koeling en conserveringsmiddelen) en dat ze daarom juist vaker worden getransporteerd uit andere gebieden. De keuze tussen gekoelde of getransporteerde producten wordt vaak echter ingegeven door beschikbaarheid in het seizoen zoals appels die uit Nieuw Zeeland komen i.p.v. uit Europese koelhuizen. Deze keuze zal voor biologische producten anders uitvallen dan voor gangbare. Daarnaast kan gekoelde opslag een kleinere of een grotere impact hebben dan transport, zodat het verschil tussen biologisch en conventioneel een balans is die beide kanten uit kan slaan (Milà i Canals et al. 2006).

Een andere reden voor méér transport is dat er minder biologische producten uit kasteelt beschikbaar is en meer uit Mediterrane gebieden. De klimaatimpact van de kasteelt is soms groter en soms kleiner dan die van het transport. Opslag kan dus een kleinere impact hebben, en transport een grotere, zodat het verschil tussen biologisch en gangbaar een balans is die beide kanten uit kan slaan. 
Er zijn ook uitzonderingen, waarbij kleinere transportafstanden ontstaan, zoals:

- Het opnemen van uit de regio afkomstige producten in het assortiment van de retail

- Het volledig betrekken van versproducten uit de regio via voedselcoöperatieven, die vaker ook biologisch zijn (enkele studies uit de UK en Cuba worden benoemd in Ziesemer 2007)

- Meer ambachtelijk geproduceerde producten in het assortiment (letterlijk, dus op kleine schaal)

Deze uitzonderingen komen ook in de gangbare tak voor. Het zou kunnen dat er grotere klimaatimpacts omdat er kleinere hoeveelheden worden met minder efficiënte vrachtwagens of busjes worden getransporteerd (Ziesemer 2007). Het kan ook dat voor dit soort producten de transport afstanden groter worden, maar misschien niet in Nederland.

\section{Retail \& Consumptie}

Er zijn geen aanwijzingen voor het bestaan van concrete verschillen tussen de retail en consumptie van biologische en gangbare producten. Het zou kunnen dat biologische retailers meer inzetten op energiebesparing, maar dat is moeilijk te bewijzen en er zijn geen publicaties over beschikbaar.

\subsubsection{Afval bij bovenstaande stappen}

\section{Tussen oogst en retail}

Het is voor te stellen dat er in alle stappen in de keten meer producten met afwijkende vormen worden geaccepteerd in de biologische tak (met name bij groente en fruit). De conventionele "lelijkerds" die het niet halen belanden vaak in soep of maaltijden, en leiden dus ook niet (per se) tot verspilling. Hier is echter veel onduidelijkheid over. Ook dit is een zogenaamde witte vlek.

\section{Retail \& Consumptie}

Houdbaarheid is een groter probleem bij biologische producten dan bij gangbare, maar de verschillen zijn zeker niet groot. Er zal waarschijnlijk meer verspilling in de retail ontstaan doordat biologische producten een lagere omzetsnelheid kennen (persoonlijke mededeling, Jan Broeze, 2018). Omdat het schap gevuld moet blijven leidt dit vermoedelijk tot een langere verblijftijd in het schap, en een iets groter aandeel dat over de houdbaarheidsdatum gaat. Het kan zijn dat het lagere gebruik van verpakkingen bij versproducten tot meer verspilling in de biologische winkel leidt. Ook is onbekend of consumenten die biologische producten consumeren bewuster met hun voedsel omgaan en daardoor minder verspillen. In de literatuur zijn echter geen duidelijke uitspraken over deze aspecten gevonden: we kunnen nu dus alleen maar speculeren over deze witte vlekken.

\subsection{Verhouding Primair vs. Post-Harvest}

Om een goede analyse voor de gehele keten te maken is het ook belangrijk om te kijken hoe de broeikasgasemissies van de primaire productie zich verhouden tot het post-harvest ketendeel. Het blijkt dat over het algemeen de impact van verwerking en transport niet zo groot is ten opzichte van de primaire productie. Dit geldt voor zowel voor biologisch als voor gangbaar. Bij dierlijke producten is de impact van de primaire productie zo groot dat de impact van de rest van de keten in verhouding beperkt is. Soms kan de klimaatimpact van dierlijke producten uit een ander continent inclusief het transport naar Europa lager zijn dan hetzelfde Europese product. Akkerbouwproducten hebben een relatief lage impact, waardoor de rest van de keten relatief een grote impact heeft. Verwerking bij producten zoals brood en pasta speelt een grote rol, en ook transport kan een grote rol spelen. Bij tuinbouwproducten kan transport over lange afstand een grote rol gaan spelen, zeker als het product ingevlogen wordt. Bij open teelten wordt voor een jaarronde beschikbaarheid een afweging gemaakt tussen producten lang gekoeld opslaan of van een ander continent importeren. Daarbij kunnen beide opties tot een significante bijdrage aan de klimaatimpact leiden. Bij beschermde teelten wordt voor jaarronde beschikbaarheid een afweging gemaakt tussen producten in kassen telen en producten uit Zuid-Europa importeren. Daarbij kunnen beide opties weer tot een significante bijdrage aan de klimaatimpact leiden.

In Tabel 10 wordt een overzicht gepresenteerd van de relatieve klimaat impacts: primaire producten ten opzichte van elkaar; ander ketenstappen t.o.v. productie. Uit deze tabel blijkt ook dat het maken van een afweging tussen emissies in de primaire productie en de afstand van transport zeker nuttig is. Veraf is niet noodzakelijkerwijs slechter. Vanuit klimaatoogpunt is er dan ook weinig meerwaarde te geven aan de discussie over lokaal produceren en consumeren. 
Tabel 10 Overzicht van de relatieve impacts op de broeikasgasemissies: primaire producten ten opzichte van elkaar; ander ketenstappen t. o.v. productie. $\mathrm{VW}=$ verwaarloosbaar. Indien gemarkeerd met een asterisk $(*)$ dan gaat het om een vermoeden, niet gebaseerd op een referentie.

\begin{tabular}{|c|c|c|c|c|c|c|c|}
\hline Product & Primair & $\begin{array}{c}\text { Verwerking \& } \\
\text { Opslag }\end{array}$ & Verpakking & Transport & Retail & Consumptie & Bron \\
\hline Rund & Zeer groot & \multicolumn{3}{|c|}{ Verwaarloosbaar } & $\mathrm{VW} *$ & $\mathrm{VW} *$ & (Webb et al. 2013; Wiedemann et al. 2015) \\
\hline Lam & Zeer groot & \multicolumn{3}{|c|}{ Zeer klein } & $\mathrm{VW}^{*}$ & $\mathrm{VW}^{*}$ & (Webb et al. 2013) \\
\hline Varken & Groot & Klein & $\mathrm{VW} *$ & Variabel maar vaak klein & $\mathrm{VW}^{*}$ & $\mathrm{VW} *$ & (Dalgaard et al. 2007) \\
\hline Kip & Groot & Middelmatig & $\mathrm{VW} *$ & Variabel maar vaak klein & $\mathrm{VW}^{*}$ & $\mathrm{VW}^{*}$ & (Webb et al. 2013) \\
\hline Melk & Groot & Klein & Zeer klein & Klein & Klein & Klein & (Thoma et al. 2018) \\
\hline Komkommer & Variabel: Klein - Groot & Verwaarloosbaar & $\mathrm{VW} *$ & Variabel: Klein - Middelgroot & $\mathrm{VW}^{*}$ & $\mathrm{VW}^{*}$ & (Stoessel et al. 2012) \\
\hline Sla & Variabel: Klein - Groot & Verwaarloosbaar & $\mathrm{VW} *$ & Variabel: Klein - Middelgroot & $\mathrm{VW}^{*}$ & VW* & (Stoessel et al. 2012) \\
\hline Tuinbouw (gem.) & Klein & Verwaarloosbaar & $\mathrm{VW}^{*}$ & Variabel: Klein - Groot & $\mathrm{VW}^{*}$ & Klein* & (Michalský and Hooda 2015) \\
\hline Aardappel & Klein & Verwaarloosbaar & VW* & Variabel: Klein - Middelgroot & $\mathrm{VW}^{*}$ & Klein* & (Webb et al. 2013) \\
\hline Brood & Klein & Klein & $\mathrm{VW} *$ & $\mathrm{VW}^{*}$ & $\mathrm{VW}^{*}$ & Klein & (Espinoza-Orias et al. 2011) \\
\hline
\end{tabular}




\section{Discussie en conclusies}

Uit de literatuur blijkt dat een vergelijking tussen biologische en gangbare landbouwsystemen nog niet eenvoudig is. Een vergelijking op gewasniveau is onwenselijk en onjuist, mede omdat de situatie veel simpeler wordt voorgesteld dan deze in feite is (oversimplificatie). Het is belangrijk om bij het doen van dergelijke vergelijkingen de systeemgrenzen steeds in acht te nemen. We zien dat veel studies daar, waarschijnlijk vanwege de complexiteit, op dit moment nog onvoldoende rekening mee houden. Ook zijn er veel metastudies verschenen waarin de milieu impact van biologische met de gangbare productiewijze is vergeleken, maar deze studies blijken soms grote wetenschappelijke hiaten te bevatten. Dit kan onder meer komen doordat bij veel uitgevoerde experimenten op (proef-) bedrijven de nulsituatie niet in kaart gebracht is, waardoor er vraagtekens kunnen worden geplaatst bij de uiteindelijk gemeten effecten. Daarnaast gaan sommige vergelijkingen mank doordat de bijdragen per unit product of per unit land wordt verward.

In deze studie zijn we uitgegaan van de emissies uitgedrukt per kg product. Vanuit klimaatoogpunt is dit een logische keuze, aangezien broeikasgasemissies voor een wereldwijd effect zorgen en minder regionale impact hebben, in tegenstelling tot emissies van bijv. ammoniak en eutrofiëring van oppervlaktewater. Bij een gelijkblijvende productie leidt een lagere footprint tot minder broeikasgasemissies. In het klimaatbeleid wordt echter uitgegaan van nationale reductiedoelstellingen, en dan kan sturen op emissies per hectare effectiever zijn dan sturen op emissies per kg product. In dat laatste geval kan namelijk de totale productie wel toenemen en daarmee ook de totale hoeveelheid emissies, zoals de afgelopen jaren is gezien in de melkveehouderij na afschaffing van de melkquotering.

Een belangrijke conclusie is dat het lastig is, zo niet onmogelijk, om een generieke uitspraak te doen wat nu beter voor het milieu is, gangbaar of biologisch. Het streven naar quick-wins binnen ketens kan leiden tot onbedoelde neveneffecten. Zo kan een streven naar verhoging van de bodemkoolstof onbedoeld ervoor zorgen dat er nieuwe problemen ontstaan, bijvoorbeeld door de emissie van $\mathrm{N}_{2} \mathrm{O}$. Voorts valt op dat er nog veel witte vlekken door de ketens heen bestaan, zowel in de primaire productie als post-harvest, die ertoe leiden dat een uitspraak over wat nu uiteindelijk beter is, biologisch of gangbaar, uitermate speculatief wordt. Daarbij moet worden aangetekend dat naarmate de complexiteit toeneemt (veehouderij of gecombineerde productiesystemen) er steeds minder studies voorhanden zijn. Ook zijn er aan het einde van de keten (bijvoorbeeld bij de retail of bij de consumptie) nog veel witte vlekken. Kortom: er dient nog veel werk te worden verzet om de betrouwbaarheid van de gegevens verder te bevorderen.

In de overzichtstabel op de volgende bladzijde (Tabel 11) geven wij een overzicht van de verschillende processen binnen de ketens voor de primaire productie en waar verschillen qua broeikasgasemissies zitten tussen de biologische en gangbare productiewijzen. Wij limiteren ons hiertoe gezien het feit dat de impact van post-harvest processen in verhouding klein is tot de primaire productie en dat juist in het achterste gedeelte van de keten nog weinig naar de vergelijking tussen biologisch en gangbaar is gekeken. Dit zou dus erg speculatief worden. Om de leesbaarheid van deze tabel te bevorderen hebben wij ervoor gekozen om de achterliggende literatuurreferenties in Bijlage 1 te plaatsen.

Tabel 11 laat zien dat in de grondgebonden sectoren de biologische landbouw lagere emissies per $\mathrm{kg}$ product kan hebben in de teelt van gewassen, door gebruik van stikstofbindende gewassen i.p.v. kunstmest en de mogelijk extra koolstofvastlegging in de landbouw. Het gebruik van meer diesel bij biologische onkruidbestrijding en het verbranden van onkruid of loof met propaan zorgt dan weer voor hogere directe $\mathrm{CO}$-emissies in de meeste biologische systemen. In de intensieve veehouderij is er door de lagere voederconversie bij biologische bedrijven meestal een hogere emissie per kg product. 
Overzichtstabel. Broeikasgasemissies uit verschillende systemen per eenheid product. Biologisch vs. gangbaar. Groen: biologisch lagere emissies per kg product, rood: gangbaar lagere emissies per kg product, geel: marginaal of onvoldoende informatie.

Primair productiesysteem

\begin{tabular}{|c|c|c|c|c|}
\hline Melkveehouderij & Akkerbouw & Tuinbouw & Varkenshouderij & \multirow{2}{*}{$\begin{array}{r}\text { Pluimvee } \\
\text { (leg/ vleeskuikens) } \\
\text { Veevoe }\end{array}$} \\
\hline Teelt veevoer & $\mathrm{N}_{2} \mathrm{O}$ bemesting & $\mathrm{N}_{2} \mathrm{O}$ bemesting & Veevoer & \\
\hline Pensfermentatie $\left(\mathrm{CH}_{4}\right)$ & $\mathrm{N}_{2} \mathrm{O}$ veldemissie & $\mathrm{N}_{2} \mathrm{O}$ veldemissie & Voederconversie & Voederconversie \\
\hline Opslag veevoer & $\mathrm{CO}_{2}$ onkruidbestrijding & $\mathrm{CO}_{2}$ onkruidbestrijding & $\begin{array}{r}\text { Houderij (uitloop \& stro; } \\
\qquad \mathrm{CO}_{2} / \mathrm{CH}_{4} / \mathrm{N}_{2} \mathrm{O} \text { ) }\end{array}$ & Houderij (uitloop) \\
\hline Houderij (weidegang) & & & & \\
\hline \multicolumn{5}{|l|}{ Uitmesten/mestopslag $\left(\mathrm{N}_{2} \mathrm{O}\right)$} \\
\hline \multicolumn{5}{|l|}{ Opfok nakomelingen } \\
\hline \multicolumn{5}{|l|}{ Melkwinning } \\
\hline Totaal & Totaal & Totaal & Totaal & Totaal \\
\hline
\end{tabular}




\section{Literatuur}

Albanito, F., U. Lebender, T. Cornulier, T. B. Sapkota, F. Brentrup, C. Stirling, and J. Hillier. 2017. Direct Nitrous Oxide Emissions From Tropical And Sub-Tropical Agricultural Systems - A Review And Modelling Of Emission Factors. Scientific Reports 7: 44235.

Basset-Mens, C., S. Ledgard, and M. Boyes. 2009. Eco-efficiency of intensification scenarios for milk production in New Zealand. Ecological Economics 68 (6): 1615-1625. http://dx.doi.org/https://doi.org/10.1016/j.ecolecon.2007.11.017.

Bikker, P., J. Van Harn, C. M. Groenestein, J. De Wit, C. Van Bruggen, and H. H. Luesink. 2013. Stikstof- en fosforexcretie van varkens, pluimvee en rundvee in biologische en gangbare houderijsystemen. Wageningen: Wageningen University \& Research.

Bos, J. F. F. P., J. d. Haan, W. Sukkel, and R. L. M. Schils. 2014. Energy use and greenhouse gas emissions in organic and conventional farming systems in the Netherlands. NJAS - Wageningen Journal of Life Sciences 68: 61-70. http://dx.doi.org/https://doi.org/10.1016/j.njas.2013.12.003.

Bos, J. F. F. P., J. J. d. Haan, and W. Sukkel. 2007. Energieverbruik, broeikasgasemissies en koolstofopslag: de biologische en gangbare landbouw vergeleken. Volledig rapport. Wageningen: Plant Research International.

Bos, J. F. F. P., H. F. M. ten Berge, J. Verhagen, and M. K. van Ittersum. 2017. Trade-offs in soil fertility management on arable farms. Agricultural Systems 157: 292-302. http://dx.doi.org/https://doi.org/10.1016/j.agsy.2016.09.013.

Braschkat, J., A. Patyk, M. Quirin, and G. A. Reinhardt. 2003. Life cycle assessment of bread production-a comparison of eight different scenarios. In Life Cycle Assessment in the Agri-food sector Proceedings from the 4th International Conference, October 6-8, 2003, Bygholm, Denmark, edited by N. Halberg. Bygholm: DIAS.

Chirinda, N., M. S. Carter, K. R. Albert, P. Ambus, J. E. Olesen, J. R. Porter, and S. O. Petersen. 2010. Emissions of nitrous oxide from arable organic and conventional cropping systems on two soil types. Agriculture, Ecosystems \& Environment 136 (3): 199-208. http://dx.doi.org/https://doi.org/10.1016/j.agee.2009.11.012.

Dalgaard, R., N. Halberg, and J. E. Hermansen. 2007. Danish pork production: an environmental assessment. In DJ F Animal Science Tjele: University of Aarhus.

de Ponti, T., B. Rijk, and M. K. van Ittersum. 2012. The crop yield gap between organic and conventional agriculture. Agricultural Systems 108: 1-9. http://dx.doi.org/https://doi.org/10.1016/j.agsy.2011.12.004.

Dekker, S. E. M., I. J. M. de Boer, I. Vermeij, A. J. A. Aarnink, and P. W. G. G. Koerkamp. 2011. Ecological and economic evaluation of Dutch egg production systems. Livestock Science 139 (1): 109-121. http://dx.doi.org/10.1016/j.livsci.2011.03.011.

Dourmad, J. Y., J. Ryschawy, T. Trousson, M. Bonneau, J. Gonzàlez, H. W. J. Houwers, M. Hviid, et al. 2014. Evaluating environmental impacts of contrasting pig farming systems with life cycle assessment. Animal 8 (12): 2027-2037. http://dx.doi.org/Doi: 10.1017/s1751731114002134.

Espinoza-Orias, N., H. Stichnothe, and A. Azapagic. 2011. The carbon footprint of bread. The International Journal of Life Cycle Assessment 16 (4): 351-365.

Flysjö, A., C. Cederberg, M. Henriksson, and S. Ledgard. 2012. The interaction between milk and beef production and emissions from land use change - critical considerations in life cycle assessment and carbon footprint studies of milk. Journal of Cleaner Production 28: 134-142. http://dx.doi.org/https://doi.org/10.1016/j.jclepro.2011.11.046.

Gattinger, A., A. Muller, M. Haeni, C. Skinner, A. Fliessbach, N. Buchmann, P. Mäder, et al. 2012. Enhanced top soil carbon stocks under organic farming. Proceedings of the National Academy of Sciences 109 (44): 18226-18231. http://dx.doi.org/10.1073/pnas.1209429109.

Gomiero, T., D. Pimentel, and M. G. Paoletti. 2011. Environmental Impact of Different Agricultural Management Practices: Conventional vs. Organic Agriculture. Critical Reviews in Plant Sciences 30 (1-2): 95-124. http://dx.doi.org/10.1080/07352689.2011.554355.

Hietala, S., L. Smith, M. T. Knudsen, S. Kurppa, S. Padel, and J. E. Hermansen. 2015. Carbon footprints of organic dairying in six European countries-real farm data analysis. Organic Agriculture 5 (2): 91 100. http://dx.doi.org/10.1007/s13165-014-0084-0.

Hijbeek, R., M. K. van Ittersum, H. F. M. ten Berge, G. Gort, H. Spiegel, and A. P. Whitmore. 2017. Do organic inputs matter - a meta-analysis of additional yield effects for arable crops in Europe. Plant and Soil 411 (1): 293-303. http://dx.doi.org/10.1007/s11104-016-3031-x.

Hülsbergen, K. J., and G. Rahmann. 2013. Klimawirkungen und Nachhaltigkeit von Landbausystemen Untersuchungen in einem Netzwerk von Pilotbetrieben. Braunschweig: Thünen Institut.

Kirchmann, H., T. Kätterer, L. Bergström, G. Börjesson, and M. A. Bolinder. 2016. Flaws and criteria for design and evaluation of comparative organic and conventional cropping systems. Field Crops Research 186: 99-106. http://dx.doi.org/https://doi.org/10.1016/j.fcr.2015.11.006. 
Kool, A., H. Blonk, T. Ponsioen, W. Sukkel, H. M. Vermeer, J. W. d. Vries, and R. Hoste. 2009. Carbon footprints of conventional and organic pork : assessments of typical production systems in the Netherlands, Denmark, England and GermanyCarbon footprints of conventional and organic pork : assessments of typical production systems in the Netherlands, Denmark, England and Germany. Gouda [etc.]: Blonk Milieu Advies [etc.].

Leifeld, J. 2016. Current approaches neglect possible agricultural cutback under large-scale organic farming. A comment to Ponisio <em $>$ et $\mathrm{al}</ \mathrm{em}>$. Proceedings of the Royal Society B: Biological Sciences 283 (1824). http://dx.doi.org/10.1098/rspb.2015.1623.

Leifeld, J., D. A. Angers, C. Chenu, J. Fuhrer, T. Kätterer, and D. S. Powlson. 2013. Organic farming gives no climate change benefit through soil carbon sequestration. Proceedings of the National Academy of Sciences. http://dx.doi.org/10.1073/pnas.1220724110.

Leifeld, J., and J. Fuhrer. 2010. Organic farming and soil carbon sequestration: what do we really know about the benefits? Ambio 39 (8): 585-99.

Leinonen, I., A. G. Williams, J. Wiseman, J. Guy, and I. Kyriazakis. 2012a. Predicting the environmental impacts of chicken systems in the United Kingdom through a life cycle assessment: Broiler production systems. Poultry Science 91 (1): 8-25.

2012b. Predicting the environmental impacts of chicken systems in the United Kingdom through a life cycle assessment: Egg production systems. Poultry Science 91 (1): 26-40.

Michalský, M., and P. S. Hooda. 2015. Greenhouse gas emissions of imported and locally produced fruit and vegetable commodities: A quantitative assessment. Environmental Science \& Policy 48: 32-43.

Milà i Canals, L., G. M. Burnip, and S. J. Cowell. 2006. Evaluation of the environmental impacts of apple production using Life Cycle Assessment (LCA): Case study in New Zealand. Agriculture, Ecosystems \& Environment 114 (2): 226-238. http://dx.doi.org/https://doi.org/10.1016/j.agee.2005.10.023.

Müller-Lindenlauf, M., C. Deittert, and U. Köpke. 2018. Assessment of environmental effects, animal welfare and milk quality among organic dairy farms. Livestock Science 128 (1): 140-148. http://dx.doi.org/10.1016/j.livsci.2009.11.013.

Owen, J. J., and W. L. Silver. 2015. Greenhouse gas emissions from dairy manure management: a review of field-based studies. Global Change Biology 21 (2): 550-565. http://dx.doi.org/doi: 10.1111/gcb.12687.

Pikula, D., H. F. M. Ten Berge, P. W. Goedhart, and J. J. Schröder. 2016. Apparent nitrogen fertilizer replacement value of grass-clover leys and of farmyard manure in an arable rotation. Part II: farmyard manure. Soil Use and Management 32 (S1): 20-31. http://dx.doi.org/doi: 10.1111/sum.12245.

Ponisio, L. C., L. K. M'Gonigle, K. C. Mace, J. Palomino, P. de Valpine, and C. Kremen. 2015. Diversification practices reduce organic to conventional yield gap. Proceedings of the Royal Society B: Biological Sciences 282 (1799). http://dx.doi.org/10.1098/rspb.2014.1396.

Powlson, D. S., A. P. Whitmore, and K. W. T. Goulding. 2011. Soil carbon sequestration to mitigate climate change: a critical re-examination to identify the true and the false. European Journal of Soil Science 62 (1): 42-55. http://dx.doi.org/doi: 10.1111/j.1365-2389.2010.01342.x.

Schmidt Rivera, X. C., N. Espinoza Orias, and A. Azapagic. 2014. Life cycle environmental impacts of convenience food: Comparison of ready and home-made meals. Journal of Cleaner Production 73: 294-309. http://dx.doi.org/https://doi.org/10.1016/j.jclepro.2014.01.008.

Seufert, V., N. Ramankutty, and J. A. Foley. 2012. Comparing the yields of organic and conventional agriculture. Nature 485: 229.

Skinner, C., A. Gattinger, A. Muller, P. Mäder, A. Fließbach, M. Stolze, R. Ruser, and U. Niggli. 2014. Greenhouse gas fluxes from agricultural soils under organic and non-organic management - A global meta-analysis. Science of The Total Environment 468-469: 553-563. http://dx.doi.org/https://doi.org/10.1016/j.scitotenv.2013.08.098.

Sneath, R. W., F. Beline, M. A. Hilhorst, and P. Peu. 2006. Monitoring GHG from manure stores on organic and conventional dairy farms. Agriculture, Ecosystems \& Environment 112 (2): 122-128. http://dx.doi.org/https://doi.org/10.1016/j.agee.2005.08.020.

Stoessel, F., R. Juraske, S. Pfister, and S. Hellweg. 2012. Life cycle inventory and carbon and water foodprint of fruits and vegetables: application to a Swiss retailer. Environmental science \& technology 46 (6): 3253-3262.

Ten Berge, H. F. M., D. Pikula, P. W. Goedhart, J. J. Schröder, and F. Nicholson. 2016. Apparent nitrogen fertilizer replacement value of grass-clover leys and of farmyard manure in an arable rotation. Part I: grass-clover leys. Soil Use and Management 32 (S1): 9-19. http://dx.doi.org/doi: 10.1111/sum.12246.

Ten Berge, H. F. M., J. J. Schröder, J. E. Olesen, and J.-V. Giraldez Cervera. 2017. Research for AGRI Committee - Preserving agricultural soils in the EU. Brussels: European Union.

Thoma, G. J., S. W. Ellsworth, and M. J. Yan. 2018. "Principles of Green Food Processing (Including Lifecycle Assessment and Carbon Footprint)." In Alternatives to Conventional Food Processing 2nd Edition, edited by A. Proctor, 516. Royal Society of Chemistry.

Tuomisto, H. L., I. D. Hodge, P. Riordan, and D. W. Macdonald. 2012. Does organic farming reduce environmental impacts? - A meta-analysis of European research. Journal of Environmental Management 112: 309-320. http://dx.doi.org/https://doi.org/10.1016/j.jenvman.2012.08.018. 
van Krimpen, M. M., F. Leenstra, V. Maurer, and M. Bestman. 2016. How to fulfill EU requirements to feed organic laying hens $100 \%$ organic ingredients. The Journal of Applied Poultry Research 25 (1): 129138.

Vellinga, T. 2012. Feedprint, a calculation tool of the feed production and utilization chain.

Wagenberg, C. P. A. v., Y. d. Haas, H. Hogeveen, M. M. v. Krimpen, M. P. M. Meuwissen, C. E. v. Middelaar, and T. B. Rodenburg. 2016. Sustainability of livestock production systems : a comparing conventional and organic livestock husbandry. Wageningen: Wageningen University \& Research.

Webb, J., A. G. Williams, E. Hope, D. Evans, and E. Moorhouse. 2013. Do foods imported into the UK have a greater environmental impact than the same foods produced within the UK? The International Journal of Life Cycle Assessment 18 (7): 1325-1343. http://dx.doi.org/10.1007/s11367-013-05762.

Wiedemann, S., E. McGahan, C. Murphy, M.-J. Yan, B. Henry, G. Thoma, and S. Ledgard. 2015. Environmental impacts and resource use of Australian beef and lamb exported to the USA determined using life cycle assessment. J ournal of Cleaner Production 94: 67-75. http://dx.doi.org/https://doi.org/10.1016/j.jclepro.2015.01.073.

Ziesemer, J. 2007. Energy use in organic food systems. Rome: FAO. 


\section{Bijlage 1 Overzicht bronnen Tabel 11}

Biologisch vs. gangbaar. Groen: biologisch lagere emissies per kg product, rood: gangbaar lagere emissies per kg product, geel: marginaal of onvoldoende informatie.

\author{
Melkveehouderij \\ Veevoer \\ Pensfermentatie $\left(\mathrm{CH}_{4}\right)$ \\ Opslag veevoer \\ Houderij (weidegang) \\ Uitmesten/mestopslag $\left(\mathrm{N}_{2} \mathrm{O}\right)$ \\ Opfok nakomelingen \\ Melkwinning \\ Totaal in $\mathrm{g} \mathrm{CO}_{2}$-eq $\mathrm{kg} \mathrm{ECM}^{-1}$
}

\section{Akkerbouw}

$\mathrm{N}_{2} \mathrm{O}$ bemesting

$\mathrm{N}_{2} \mathrm{O}$ veldemissie

$\mathrm{CO}_{2}$ onkruidbestrijding

Totaal in $\mathrm{g} \mathrm{CO}_{2}$-eq $\mathrm{kg}_{\text {product }}{ }^{-1}$

\section{Tuinbouw}

$\mathrm{N}_{2} \mathrm{O}$ bemesting

$\mathrm{N}_{2} \mathrm{O}$ veldemissie

$\mathrm{CO}_{2}$ onkruidbestrijding

Totaal in $\mathrm{g} \mathrm{CO}_{2}$-eq $\mathrm{kg}$ product- 1

\section{Varkenshouderij}

Veevoer

Voederconversie

Houderij (uitloop \& stro; $\mathrm{CO}_{2} / \mathrm{CH}_{4} / \mathrm{N}_{2} \mathrm{O}$ )

Totaal in $\mathrm{g} \mathrm{CO}_{2}$-eq $\mathrm{kg}$ product ${ }^{-1}$

\section{Pluimvee (leg/ vleeskuikens) \\ Veevoer \\ Voederconversie}

Houderij (uitloop)

Totaal in $\mathrm{g} \mathrm{CO}_{2}$-eq $\mathrm{kg}$ product $^{-1}$

\section{Referenties}

(Hülsbergen and Rahmann 2013)

(Hülsbergen and Rahmann 2013)

(Hülsbergen and Rahmann 2013)

(Hülsbergen and Rahmann 2013)

(Hülsbergen and Rahmann 2013; Sneath et al. 2006)

(Hülsbergen and Rahmann 2013)

(Hülsbergen and Rahmann 2013)

(Hülsbergen and Rahmann 2013; Bos et al. 2014)

(Skinner et al. 2014)

(Chirinda et al. 2010; Skinner et al. 2014)

(Bos et al. 2014)

(Bos et al. 2014)

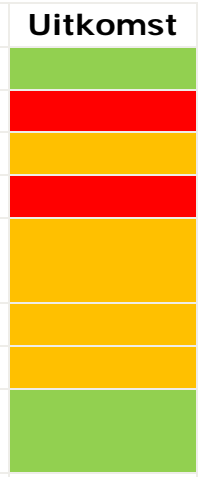

(Bos et al. 2014)

(Bos et al. 2014)

(Bos et al. 2014)

(Bos et al. 2014)
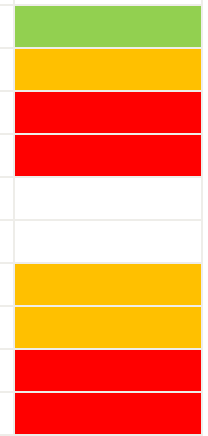

(Dourmad et al. 2014; Kool et al. 2009)

(Dourmad et al. 2014; Bikker et al. 2013; van Krimpen et al. 2016)

(Dourmad et al. 2014) \{Kool, 2009 \#30\}

(Dourmad et al. 2014; Kool et al. 2009)

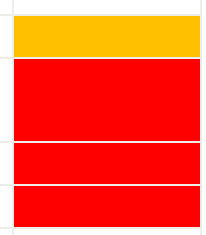

(Leinonen et al. 2012a, 2012b)

(Leinonen et al. 2012a; Bikker et al. 2013; van Krimpen et al. 2016; Leinonen et al. 2012b)

(Leinonen et al. 2012a, 2012b)

(Leinonen et al. 2012a, 2012b; Dekker et al. 2011) 


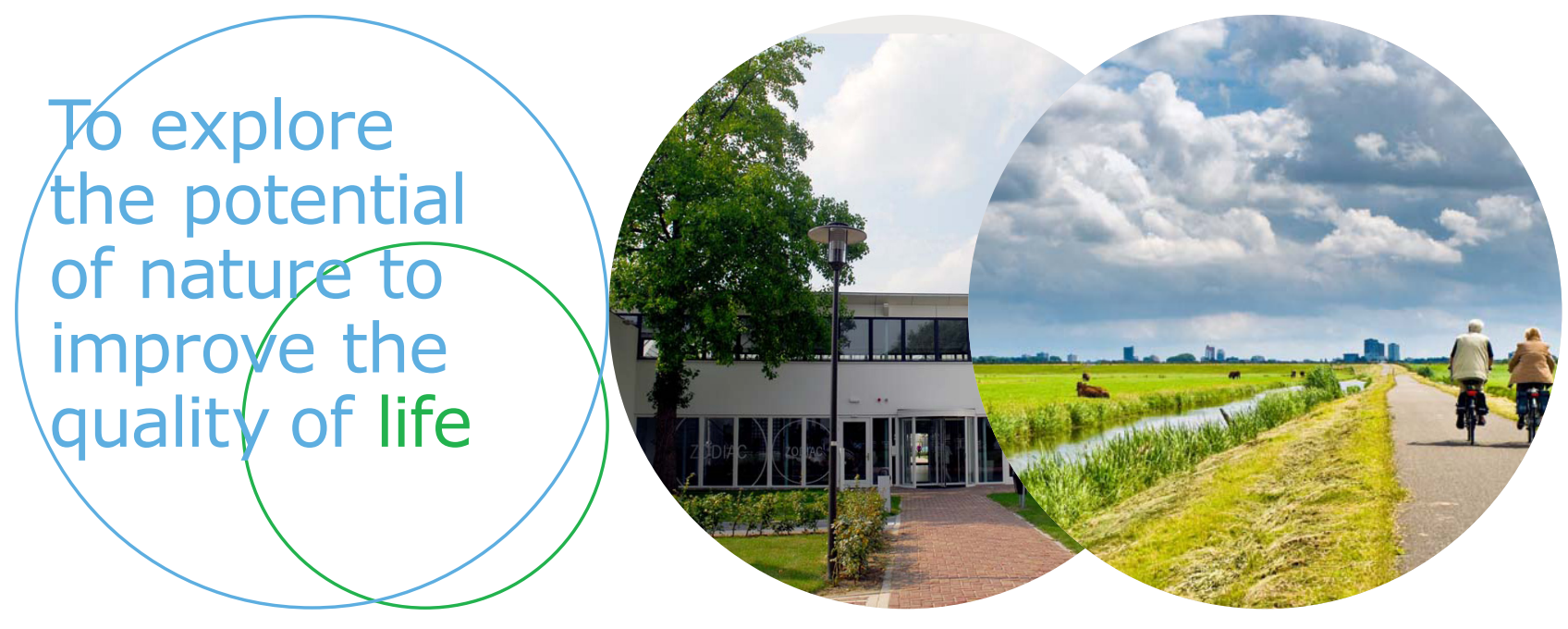

Wageningen Livestock Research Postbus 338

Wageningen Livestock Research ontwikkelt kennis voor een zorgvuldige en 6700 AH Wageningen

T 0317483953

renderende veehouderij, vertaalt deze naar praktijkgerichte oplossingen en innovaties, en zorgt voor doorstroming van deze kennis. Onze wetenschappelijke E info.livestockresearch@wur.nl www.wur.nl/ livestock-research kennis op het gebied van veehouderijsystemen en van voeding, genetica, welzijn en milieu-impact van landbouwhuisdieren integreren we, samen met onze klanten, tot veehouderijconcepten voor de $21 \mathrm{e}$ eeuw.

De missie van Wageningen University \& Research is 'To explore the potential of nature to improve the quality of life'. Binnen Wageningen University \& Research bundelen 9 gespecialiseerde onderzoeksinstituten van Stichting Wageningen Research en Wageningen University hun krachten om bij te dragen aan de oplossing van belangrijke vragen in het domein van gezonde voeding en leefomgeving. Met ongeveer 30 vestigingen, 6.500 medewerkers en 10.000 studenten behoort Wageningen University \& Research wereldwijd tot de aansprekende kennisinstellingen binnen haar domein. De integrale benadering van de vraagstukken en de samenwerking tussen verschillende disciplines vormen het hart van de unieke Wageningen aanpak. 